\title{
Buffer clustering policy for sequential production lines with deterministic processing times
}

\author{
Francesca Schuler* and Houshang Darabi
}

Mechanical and Industrial Engineering, University of Illinois, Chicago, USA

\begin{tabular}{l}
\hline C H R O N I C L E \\
\hline Article history: \\
Received April 42016 \\
Received in Revised Format \\
April 272016 \\
Accepted May 62016 \\
Available online \\
May 62016 \\
\hline Keywords: \\
Sequential \\
Production \\
Buffer \\
Cluster \\
Deterministic \\
Configuration
\end{tabular}
\begin{abstract}
A B S T R A C T
A sequential production line is defined as a set of sequential operations within a factory or distribution center whereby entities undergo one or more processes to produce a final product. Sequential production lines may gain efficiencies such as increased throughput or reduced work in progress by utilizing specific configurations while maintaining the chronological order of operations. One problem identified by the authors via a case study is that, some of the configurations, such as work cell or U-shaped production lines that have groups of buffers, often increase the space utilization. Therefore, many facilities do not take advantage of the configuration efficiencies that a work cell or U-shaped production line provide. To solve this problem, the authors introduce the concept of a buffer cluster. The production line implemented with one or more buffer clusters maintains the throughput of the line, identical to that with dedicated buffers, but with the clusters reduces the buffer storage space. The paper derives a time based parametric model that determines the sizing of the buffer cluster, provides a reduced time space for which to search for the buffer cluster sizing, and determines an optimal buffer clustering policy that can be applied to any $\mathrm{N}$-server, $\mathrm{N}+1$-buffer sequential line configuration with deterministic processing time. This solution reduces the buffer storage space utilized while ensuring no overflows or underflows occur in the buffer. Furthermore, the paper demonstrates how the buffer clustering policy serves as an input into a facility layout tool that provides the optimal production line layout.
\end{abstract}

\section{Introduction}

A sequential production line is defined as a set of sequential operations within a factory or distribution center whereby entities undergo one or more processes to produce a final product. Manufacturing and distribution facilities are facing growing competition and searching for ways to maximize production efficiency to remain competitive (Aghazadeh et al., 2011). Facilities are assessing alternate production line configurations to gain production efficiencies such as throughput increases or work in progress reduction while maintaining the chronological order of operations. A case study of a manufacturing facility (details found in section 4) desired to transition from a serial line configuration (Fig. 1) to a

* Corresponding author. Tel: +1 (224) 715-6799

E-mail: fruffo2@uic.edu (F. Schuler)

(C) 2016 Growing Science Ltd. All rights reserved. doi: $10.5267 /$ j. ijiec.2016.5.001 
configuration in Fig. 2 called a hybrid serial-work cell configuration to gain increased throughput. As a result of this change, the facility encountered a production floor space utilization problem. In these figures, the squares without a grid pattern represent server stations where a process step occurs. The squares with a grid pattern represent buffers. The stations may be manual, semi-automated, or fully automated. The groups of buffers in Fig. 2 may vary in the number of buffers within the work cell and the number of serial stations in between the work cells as shown.

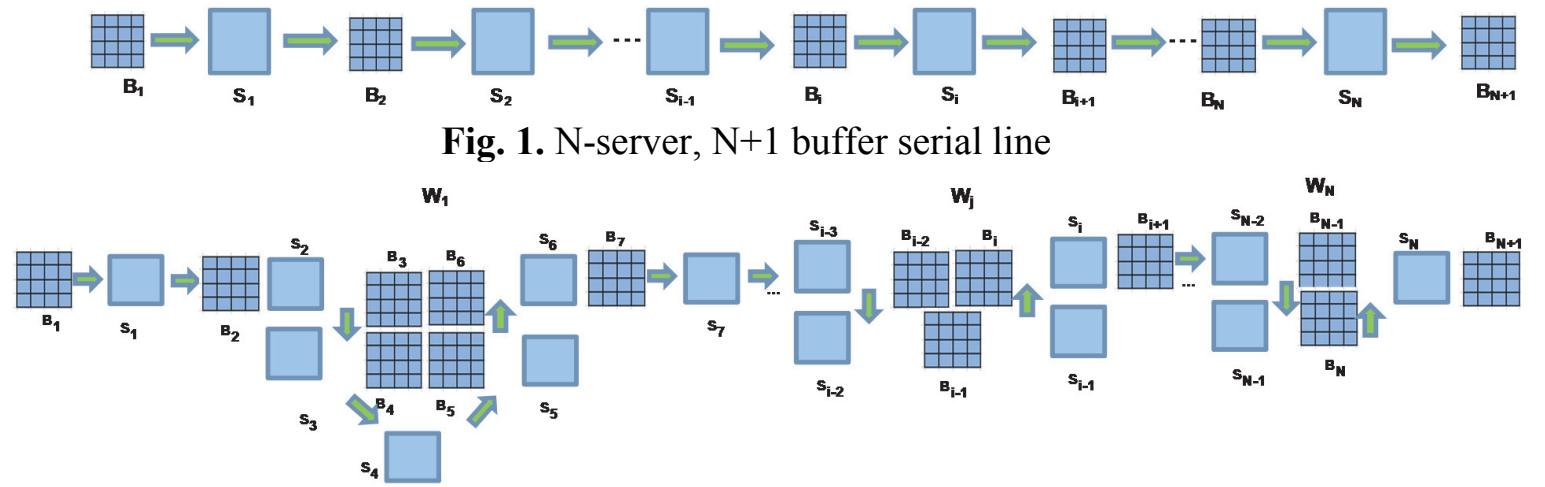

Fig. 2. Variable station work cells with one or more serial stations in between

In this scenario, because the buffers were sized separately (i.e. dedicated buffers) with respect to the serial line and grouped in the center of the work cell, the grouped buffers were not leveraging available space in the neighboring buffers during the production shift. Therefore, the work cell exceeded the typical space of the production line. The authors proposed transitioning the grouped buffers in the center of the work cell to a single buffer cluster shown in Fig. 3 which enables increased buffer utilization and reduces the size of the grouped buffers, reducing the buffer storage space. This allows the facility to benefit from efficiencies (e.g., increased throughput, work in progress reduction) by use of alternate configurations. In addition, discussed in the case study in section 4 is how sensitivity analysis of the buffer cluster size can be conducted using the models derived herein varying parameters such as the production demand and process times.

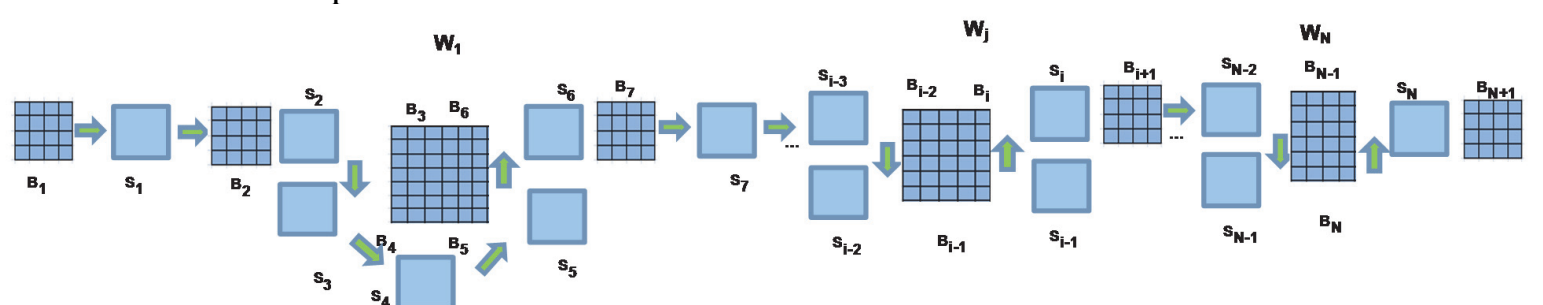

Fig. 3. Variable station work cells with serial stations in between using buffer cluster concept

In the case of this facility in a manual environment, as with many facilities globally, the use of a bar code or radio frequency identification (RFID) is utilized which aids in facilitating the buffer cluster concept. Each time a product moves from one station to another, the product bar code or RFID is scanned to ensure the prior processes are completed. Only if the prior processes are completed is that product picked from the buffer for the operator to perform the process at that station. Once the process is completed, the operator scans the product to inform the system that this process has been completed and puts the product back into the buffer. While the server or operator is processing an entity, the system via RFID identifies the next part(s) for the server / operator to pick up and notifies the operator via a light or other indicator. Thus there is no impact to the process times. Similarly, in a more fully automated environment, while the station is processing an existing entity, RFID technology identifies the next entity to process; a robot picks it up and delivers the entity to the station for processing. The buffer cluster may be partitioned and marked such that each station has a core area utilized by only that station and a shared area. Operators or robots first focus on filling their core area and then move to the shared area if needed. 
Once the buffer clustering policy is identified for a production line, an activity relationship chart is created for the buffers and stations in the production line and the amount of space assigned to each activity is determined. From the space relationship diagram, one or more feasible layout concepts are generated. The optimal production line layout is then selected.

This paper proceeds with a literature review in the second section. The third section describes the problem formulation and derives the model that is used to solve the size of the buffer cluster for any Nserver, $\mathrm{N}+1$-buffer, sequential line. An optimization framework is derived that enables a buffer clustering policy and provides an output of the buffer sizing for that policy that ensures no buffer overflows. In the fourth section, the authors apply the model to the case study and review the results. The final section discusses the conclusions.

\section{Literature review}

Given the industry example discussed in the introduction, how the research at hand differs from the prior art is assessed. Quantitative analysis of production lines includes the line balancing problem (Becker \& Scholl, 2006), the buffer allocation problem (Charharsooghi \& Nahavandi, 2003), queuing network performance and blocking (Govil \& Fu, 1999; Li et al., 2009). Literature also discusses these concepts explored with the addition of flexible manufacturing systems with varying configurations (serial, sequential, work-cells) and product types (Senanayake \& Subramaniam, 2013; So, 1989).

The line balancing problem includes the positioning and sizing of the buffers and the overall throughput resulting in the buffer allocation problem. Wei et al. (1989) estimate stochastically via optimization the buffer size in a serial manufacturing system. Chaharsooghi and Nahavandi (2003) present a heuristic algorithm to find the optimal allocation of buffers that maximizes throughput. Yamashita and Altiok (1998) implement a dynamic programming algorithm that uses decomposition to minimize buffer allocation but still meeting target throughput in production lines with phase-type processing times. There are several buffer allocation strategies: (1) Equal Buffer allocates buffers equally over the line, (2) Chow's Rule (Chow, 1987) uses dynamic programming to solve the buffer allocation problem with a fixed total buffer size, (3) L\&L's Rule (Liu \& Lin (1994)), uses a different set of equations than Chow to estimate the throughput and (4) C\&N's rule (Chan \& Ng (2002)) where all possible allocations of buffers are tried and then the allocation with the highest estimated throughput is selected. Gershwin and Schor (1999) minimize the total buffer space using a production rate constraint while maximizing production rate using a total buffer space constraint. Enginarlar et al. (2000) ensure the smallest level of buffering with the desired production rate in serial lines with unreliable machines. Enginarlar et al. (2002) also introduces the concept of Lean Level of Buffering where buffer capacity is normalized and production line efficiency is achieved using exact methods for three machine lines and estimation methods for lines with more than three machines.

Queuing network performance literature includes quantitative analysis for production systems and considers production rates, average buffer levels and probabilities of blockage (Govil \& Fu, 1999; Li et al., 2009). Gershwin (1987) developed a method using conservation of flow for evaluation of performance measures for lines with finite buffers. Lim et al. (1990) developed an aggregation method that converges on a production rate eliminating the need for simulations. Kouikoglou and Phillis (1991, 1994 and 1995) use a probabilistic technique that observes a limited number of events which are sufficient to determine the system performance and average buffer sizes. Morrison (2010) demonstrates that flow line models with deterministic service times using recursion to calculate the overall delay of entities in the system.

Considering flexible manufacturing systems and work cell literature, Ramirez-Serrano and Benhabib (2000) introduce a control algorithm to analyze concurrent operation of supervisors to determine absence of deadlocks within a work-cell. Outside of supervisory control, there have been several studies that 
investigate the utilization of work-cell and reconfigurable manufacturing systems to increase the efficiency and capacity of production lines. Ichikawa's study (2009), for example, investigates a laptop production system and optimizing the supply of parts via material handlers from the receiving area to the cells. Another study (Aghazadeh et al., 2011) analyzes use of product-oriented layout, material handling and layout of work-cells to maximize production efficiency in areas such as average units produced per day, labor cost per unit and distance traveled to procure parts. Logendran and Karim (2003) uses a nonlinear programming model consisting of binary and integer variables and a tabu search type algorithm to determine the availability of alternative locations for a work-cell and the use of alternative routes to move part loads between cells when capacity is limited. Youssef and ElMaraghy (2007) introduce a configuration selection approach that minimizes reconfiguration effort but still supports the capacity needs of production. Matta et al. (2005) use discrete event simulation and graph theory to demonstrate that technological devices moving entities from a machine to a single common buffer area of the system can improve production rates.

This paper differs from the prior literature reviewed in that it presents methods for extracting the buffer size where the buffer space is shared by several stations (via a buffer cluster) using methods derived from state space parameters with respect to time for any sequential $\mathrm{N}$-server, $\mathrm{N}+1$-buffer production line. The buffer sizing model is then utilized in an optimization framework that enables setting of the policy specifying the buffers that can be clustered ensuring no buffer overflows. The model provides an output of the required buffer cluster sizing for that policy and allows the facility to set the policy that minimizes space utilization of the production line.

\section{Buffer cluster model}

The buffer cluster model is presented in two parts. The first part (section 3.1) is the problem formulation where no clustering is assumed. This provides the model ultimately used for sizing the buffer cluster for any $\mathrm{N}$-server, $\mathrm{N}+1$-buffer sequential production line. In the second part (section 3.2), the model in section 3.1 is extended to a buffer cluster. Section 3.2 derives the optimization framework that determines the buffer cluster sizing required and enables a buffer clustering policy.

\subsection{Buffer sizing problem formulation}

In this section, the parameters used for deriving the formulation ultimately used for sizing the buffer cluster in any $\mathrm{N}$-server, $\mathrm{N}+1$-buffer sequential production line are defined. The number of arrivals and departures at Server $S_{i}, \mathrm{i}=1,2 \ldots \mathrm{N}$ by any given time t are calculated. Next the number of arrivals and departures from any buffer $B_{i}, \mathrm{i}=1,2, \ldots \mathrm{N}+1$ by any given time $\mathrm{t}$ are derived. The relationships are generated to derive the maximum number of entities (parts) a buffer will experience and the number of entities at any given time $t, B_{i}(t)$. $B_{i}(t)$ is then extended in section 3.2 to determine the buffer cluster size. Before deriving the aforementioned relationships, the notations, assumptions and definitions are listed.

\section{Notations:}

$\mathrm{N} 1) \mathrm{K} 1=$ Magnitude of inventory at $B_{1}$ at time $\mathrm{t}=0, \mathrm{~K} 1=1,2, \ldots \mathrm{N}$ (Constant).

N2) $\mathrm{BA}_{\mathrm{i}}(\mathrm{t})=$ Cumulative number of arrivals at buffer $B_{i}$ by time $\mathrm{t}, \mathrm{i}=1,2, \ldots \mathrm{N}+1$.

N3) $\mathrm{BD}_{\mathrm{i}}(\mathrm{t})=$ Cumulative number of departures from buffer $B_{i}$ by time $\mathrm{t}, \mathrm{i}=1,2, \ldots \mathrm{N}+1$.

N4) $\mathrm{SA}_{\mathrm{i}}(\mathrm{t})=$ Cumulative number of arrivals at server $S_{i}$ by time $\mathrm{t}, \mathrm{i}=1,2, \ldots \mathrm{N}$.

N5) $\mathrm{SD}_{\mathrm{i}}(\mathrm{t})=$ Cumulative number of departures from server $S_{i}$ by time t, $\mathrm{i}=1,2, \ldots \mathrm{N}$.

N6) $\mathrm{T}_{\mathrm{i}}, \mathrm{i}=1 \ldots \mathrm{N}$ is the service time for server $S_{i}, \mathrm{i}=1 \ldots \mathrm{N}$ (This includes both the process time of the unit and the transportation time of the unit from the buffer to the station and the station to the next buffer). 
Assumptions:

A1) Each Server $S_{i}$ can process at most one entity at a time (capacity =1).

A2) Each buffer $B_{i}, \mathrm{i}=1 \ldots \mathrm{N}+1$, has a capacity greater or equal to the starting inventory.

A3) Service time $T_{i}$ for each server $S_{i}$ is deterministic.

A4) At $\mathrm{t}=0^{-} \mathrm{K} 1$ is located in buffer $B_{1}$ and all other buffers are empty.

A5) At time $t=0, B_{1}$ has a departure and $S_{1}$ has an arrival.

A6) Buffer $B_{l}$ has only departures while Buffer $B_{N+l}$ has only arrivals and every buffer $B_{i}$ in between has both departures and arrivals; $\mathrm{BA}_{1}(\mathrm{t})=0 ; \mathrm{BD}_{\mathrm{N}+1}(\mathrm{t})=0$ as shown in Fig. 1.

A7) If there is at least one part in $B_{i}$ and $S_{i}$ is idle, then with no delay, an entity (part) is moved to $S_{i}$ for processing.

A8) Machines are reliable.

\section{Definitions:}

D1) $\mathrm{MT}_{\mathrm{i}}=\max \left[\mathrm{T}_{1}, \mathrm{~T}_{2} \ldots \mathrm{T}_{\mathrm{i}}\right], \mathrm{i}=1,2, \ldots \mathrm{N}$.

D2) $\tau_{\mathrm{i}}=\sum_{\mathrm{j}=1}^{\mathrm{i}} \mathrm{T}_{\mathrm{j}}, \mathrm{i}=1,2 \ldots . \mathrm{N}$, and $\tau_{0}=0$.

D3) $\mathrm{MB}_{\mathrm{i}}=$ Maximum number of entities that buffer $B_{i}, \mathrm{i}=2, . ., \mathrm{N}$ will experience.

D4) $L\rfloor$ is a floor function that maps a real number to the largest previous integer value.

D5) It is trivial to see that the frequency of arrivals to server $S_{i}$ is $\frac{1}{\mathrm{MT}_{i}}$.

A framework utilizing deterministic process times is used as in practice data is not available to determine the correct process time probability distributions. In addition, probabilistic models do not allow production line managers to keep a pulse of the production line by knowing the status of each buffer or station at any given time. This framework enables sensitivity analysis by varying process times for one or more stations which will be shown in the case study (section 4).

This model supports adding inventory (that could be in the form of batches of varying sizes) anytime before the last item in inventory $B_{1}$ leaves the first server $S_{1}$ (i.e. a batch can be added anytime before $t$ $\left.=\tau_{\mathrm{i}-1}+(\mathrm{K} 1-1) * \mathrm{MT}_{\mathrm{i}}\right)$. $\mathrm{K} 1$ can be either the initial inventory or a summation of inventory (in the form of batches) throughout the shift.

The number of arrivals and departures from server $S_{i}$ are now calculated.

Theorem 1: For the sequential system the cumulative arrivals and cumulative departures at server $S_{i}$ at time $t$ is:

$$
\begin{aligned}
& \mathrm{SA}_{\mathrm{i}}(\mathrm{t})=\left\{\begin{array}{cc}
\min \left\{\mathrm{K} 1,1+\left\lfloor\frac{\mathrm{t}-\tau_{\mathrm{i}-1}}{\mathrm{MT}_{\mathrm{i}}}\right\rfloor\right\} \text { if } \mathrm{t} \geq \tau_{\mathrm{i}-1} \\
0 & \text { Otherwise }
\end{array}\right. \\
& \mathrm{SD}_{\mathrm{i}}(\mathrm{t})=\left\{\begin{array}{l}
\min \left\{\mathrm{K} 1,1+\left\lfloor\frac{\mathrm{t}-\tau_{\mathrm{i}}}{\mathrm{MT}_{\mathrm{i}}}\right\rfloor\right\} \text { if } \mathrm{t} \geq \tau_{\mathrm{i}} \\
0 \quad \text { Otherwise }
\end{array}\right.
\end{aligned}
$$

Proof: First, Eq. (1) holds for $\mathrm{i}=1$ is shown. At $\mathrm{i}=1, \tau_{1}=\sum_{\mathrm{j}=1}^{\mathrm{i}} \mathrm{T}_{\mathrm{j}}=\mathrm{T}_{1}=\mathrm{MT}_{1} \cdot \tau_{0}=0$. Based on the sequential line assumption, at time $\mathrm{t}=0$, one part is loaded to server $S_{1}$ (recall that $\mathrm{K} 1 \geq 1$ ). This part is processed for $T_{1}=\tau_{1}$ units of time and if buffer $B_{1}$ still carries a part, server $S_{1}$ is loaded again. This loading operation (arrival event) happens at time $\mathrm{t}=\tau_{1}$. Continuing with this pattern, one can see that server $S_{l}$ is loaded at time stamp $0, \tau_{1}, 2 \tau_{1}, \ldots, \mathrm{K} 1 \tau_{1}$, therefore the last loading of server $S_{l}$ happens at time $\mathrm{t}=\mathrm{K} 1 \tau_{1}$. After this time no loading occurs as all the parts in buffer $B_{1}$ have been depleted, and the total number of arrivals to $S_{l}$ remains K1. This means that the cumulative number of arrivals to server $S_{l}$ at time $t$ can be shown by:

$$
\mathrm{SA}_{1}(\mathrm{t})=\left\{\begin{array}{lr}
\left\lfloor\frac{\mathrm{t}}{\tau_{1}}\right\rfloor+1 & 0 \leq \mathrm{t}<K 1 \tau_{1} \\
\mathrm{~K} 1 & \mathrm{t} \geq K 1 \tau_{1}
\end{array}\right.
$$


and it can immediately be concluded that $\mathrm{SA}_{1}(\mathrm{t})=\min \left\{\mathrm{K} 1,1+\left\lfloor\frac{\mathrm{t}}{\tau_{1}}\right\rfloor\right\}, \mathrm{t} \geq 0$.

This proves that Eq. (1) holds for $\mathrm{i}=1$. Second, Eq. (1) is proven to hold for $S_{i}$ where $1<\mathrm{i} \leq \mathrm{N}$. By definition for $\mathrm{t}<\tau_{i-1}, \mathrm{SA}_{\mathrm{i}}(\mathrm{t})=0$ and for $\mathrm{t}=\tau_{i-1}, \mathrm{SA}_{\mathrm{i}}(\mathrm{t})=1$. Fig. 4 is based on the result of definition D5. It shows that the cumulative arrivals to server $S_{i}$ at any time t. The interarrival times are $\mathrm{MT}_{\mathrm{i}}$. The case where $1<\mathrm{SA}_{\mathrm{i}}(\mathrm{t}) \leq \mathrm{K} 1$ is now considered.

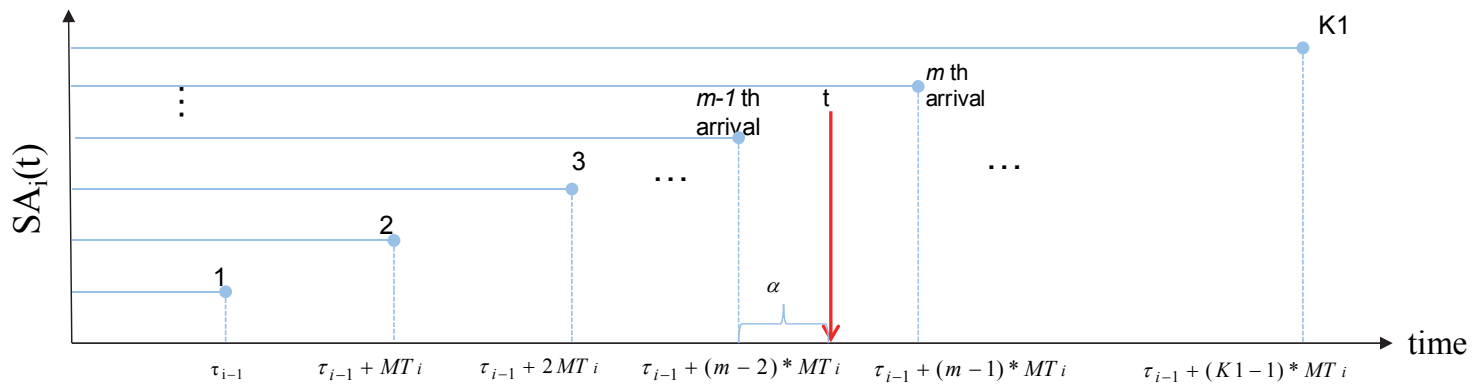

Fig. 4. Time defined for $\mathrm{SA}_{\mathrm{i}}(\mathrm{t})$ from 1 through $\mathrm{K} 1^{\text {th }}$ arrival

Assume that $\tau_{\mathrm{i}-1}+(\mathrm{m}-2) * \mathrm{MT}_{\mathrm{i}}<\mathrm{t}<\tau_{\mathrm{i}-1}+(\mathrm{m}-1) * \mathrm{MT}_{\mathrm{i}}$ where $m-1$ is an integer number and is the number of arrivals before t. From the relationship that the frequency of arrivals to Server $S_{i}$ is $\frac{1}{\mathrm{MT}_{\mathrm{i}}}$ and that for the $m-1$ th and $m$ th arrivals, time is defined in the following interval: $\tau_{\mathrm{i}-1}+(\mathrm{m}-2) * \mathrm{MT}_{\mathrm{i}}<\mathrm{t}<$ $\tau_{\mathrm{i}-1}+(m-1) * \mathrm{MT}_{\mathrm{i}}$,

$\mathrm{t}$ is defined as:

$\mathrm{t}=\tau_{\mathrm{i}-1}+(\mathrm{m}-2) * \mathrm{MT}_{\mathrm{i}}+\alpha^{*} \mathrm{MT}_{\mathrm{i}}$ where $0<\alpha \leq 1$

$\mathrm{t}-\tau_{\mathrm{i}-1}=((\mathrm{m}-2)+\alpha)^{*} \mathrm{MT}_{\mathrm{i}}$

When $\alpha=1$, the coefficient $((\mathrm{m}-2)+\alpha)=\mathrm{m}-1=\left\lfloor\frac{\mathrm{t}-\mathrm{\tau}_{\mathrm{i}-1}}{\mathrm{M \textrm {T } _ { \mathrm { i } }}}\right\rfloor$ and $S_{i}$ experiences the $\mathrm{mth}$ arrival. For $0<$ $\alpha<1$, the coefficient $=\lfloor(\mathrm{m}-2)+\alpha\rfloor=\mathrm{m}-2=\left\lfloor\frac{\mathrm{t}-\tau_{\mathrm{i}-1}}{\mathrm{MT}}\right\rfloor$ and $S_{i}$ has experienced the $\mathrm{m}-1$ th arrival. Therefore, for $1 \leq \mathrm{SA}_{\mathrm{i}}(\mathrm{t}) \leq \mathrm{K} 1, \mathrm{SA}_{\mathrm{i}}(\mathrm{t})=1+\left\lfloor\frac{\mathrm{t}-\tau_{\mathrm{i}-1}}{\mathrm{MT}_{\mathrm{i}}}\right\rfloor$. Based on the definition of arrival and departure of entities from server $S_{l}$ one can see that because of the relationship

$\mathrm{SD}_{\mathrm{i}}(\mathrm{t})=\mathrm{SA}_{\mathrm{i}}\left(\mathrm{t}+\mathrm{T}_{\mathrm{i}}\right)$

that means Eq. (2) holds.

Corollary 1: For the sequential system described in Fig. 1 the cumulative arrivals and cumulative departures at buffer $B_{i}$ at time t are:

$$
\begin{aligned}
& \mathrm{BA}_{\mathrm{i}}(\mathrm{t})=\left\{\begin{array}{c}
\min \left\{\mathrm{K} 1,1+\left\lfloor\frac{\mathrm{t}-\tau_{\mathrm{i}-1}}{\mathrm{MT} \mathrm{T}-1}\right\rfloor\right\} \text { if } \mathrm{t} \geq \tau_{\mathrm{i}-1} \\
0 \quad \text { Otherwise }
\end{array}\right.
\end{aligned}
$$

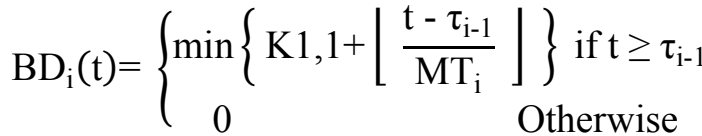

Proof: For any $B_{i}$ where $\mathrm{i}=2,3 \ldots \mathrm{N}+1$, the number of arrivals at $B_{i}$ is equal to the number of departures from $S_{i-1}$ at a given time t. Therefore taking Eq. (2) from the perspective of $S_{i-1}$ and applying the condition from Eq. (6) proves Eq. (4).

$$
\mathrm{BA}_{\mathrm{i}}(\mathrm{t})=\mathrm{SD}_{\mathrm{i}-1}(\mathrm{t})
$$

The number of departures from $B_{i}$ is equal to the number of arrivals at server $S_{i}$. Therefore, taking Eq. (1) from the perspective of arrivals at $S_{i}$ and applying the condition from Eq. (7) proves Eq. (5). 


$$
\mathrm{BD}_{\mathrm{i}}(\mathrm{t})=\mathrm{SA}_{\mathrm{i}}(\mathrm{t})
$$

Corollary 2: For the sequential system, the maximum number of entities that buffer $B_{i}$ will experience given starting inventory $\mathrm{K} 1$ as shown in Fig. 5 is:

$$
\mathrm{MB}_{\mathrm{i}}=(\mathrm{K} 1-1)-\left\lfloor\mathrm{Y}_{\mathrm{i}}^{*}(\mathrm{~K} 1-1)\right\rfloor
$$

Where $Y_{i}=\frac{\mathrm{MT}_{\mathrm{i}-1}}{\mathrm{MT}_{\mathrm{i}}}$ for $\mathrm{i}=2 \ldots \mathrm{N}$.

When $\mathrm{T}_{\mathrm{i}}>\mathrm{MT}_{\mathrm{i}-1}$, then $\mathrm{MT}_{\mathrm{i}-1}<\mathrm{MT}_{\mathrm{i}}$ and $\mathrm{Y}_{\mathrm{i}}<1$. When $\mathrm{T}_{\mathrm{i}} \leq \mathrm{MT}_{\mathrm{i}-1}$, then $\mathrm{MT}_{\mathrm{i}}=\mathrm{MT}_{\mathrm{i}-1}$ and $\mathrm{Y}_{\mathrm{i}}=1$.

This is proven for $\mathrm{MB}_{\mathrm{i}}, \mathrm{i}=2,3, \ldots \mathrm{N}$ and when $\mathrm{Y}_{\mathrm{i}}<1$.

When $Y_{i}=1, M B_{i}=0$, thus a buffer size $=1$ is required for transport only to the next process. This is called a transport buffer and $\mathrm{MB}_{\mathrm{i}}=1$ is assigned.

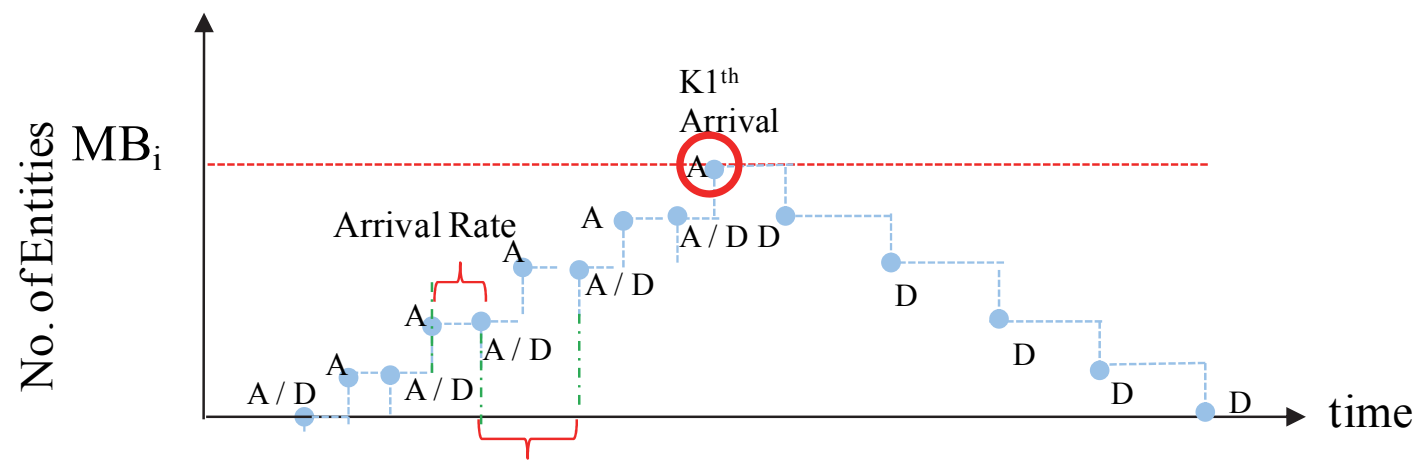

Departure Rate

Fig. 5. Maximum number of entities that buffer $B_{i}$ will experience given inventory $K 1$

For $B_{i}$ of interest, at any given time t the number of entities is equal to:

$$
\mathrm{B}_{\mathrm{i}}(\mathrm{t})=\mathrm{BA}_{\mathrm{i}}(\mathrm{t})-\mathrm{BD}_{\mathrm{i}}(\mathrm{t}), \quad \mathrm{B}_{\mathrm{i}}(\mathrm{t}) \geq 0
$$

The time ( say T) when $\mathrm{B}_{\mathrm{i}}(\mathrm{t})$ reaches its maximum level is derived and then entered into Eq. (9), therefore calculating $\mathrm{MB}_{\mathrm{i}}$. By assumption, the first departure from $S_{i-1}$ and the first arrival to $S_{i}$ happen simultaneously. After this event, because $\mathrm{MT}_{\mathrm{i}}=\mathrm{T}_{\mathrm{i}}>\mathrm{MT}_{\mathrm{i}-1}$ and using the relationship that the frequency of arrivals to Server $S_{i}$ is $\frac{1}{\mathrm{MT}_{\mathrm{i}}}$, the departure rate from $S_{i-1}$ will be greater than the arrival rate to $S_{i}$. This causes the accumulation in $B_{i}$ to increase until the last departure (K1th departure) from $S_{i-1}$ occurs. Therefore the maximum accumulation happens when the last departure from $S_{i-1}$ occurs.

$$
\mathrm{T}=\mathrm{MT}_{\mathrm{i}-1} *(\mathrm{~K} 1-1)+\tau_{\mathrm{i}-1}
$$

Plugging in T from Eq. (10) into Eq. (11) and using the results of Corollary 1:

$$
\begin{aligned}
& \mathrm{B}_{\mathrm{i}}(\mathrm{t})=\mathrm{BA}_{\mathrm{i}}(\mathrm{t})-\mathrm{BD}_{\mathrm{i}}(\mathrm{t})=\min \left(\mathrm{K} 1,1+\left\lfloor\frac{\mathrm{t}-\tau_{\mathrm{i}-1}}{\mathrm{MT}_{\mathrm{i}-1}}\right\rfloor\right)-\min \left(\mathrm{K} 1,1+\left\lfloor\frac{\mathrm{t}-\tau_{\mathrm{i}-1}}{\mathrm{MT}_{\mathrm{i}}}\right\rfloor\right) \\
= & \mathrm{MB}_{\mathrm{i}}=\left\lfloor\frac{\mathrm{MT}_{\mathrm{i}-1} *(\mathrm{~K} 1-1)}{\mathrm{MT}_{\mathrm{i}-1}}\right\rfloor-\left\lfloor\frac{\mathrm{MT}_{\mathrm{i}-1} *(\mathrm{~K} 1-1)}{\mathrm{MT} T_{\mathrm{i}}}\right\rfloor=(\mathrm{K} 1-1)-\left\lfloor\mathrm{Y}_{\mathrm{i}} *(\mathrm{~K} 1-1)\right\rfloor
\end{aligned}
$$

\subsection{Optimization framework formulation for buffer clustering policy}

In this part, the buffer clustering optimization framework is derived utilizing the model from section 3.1 to provide the buffer cluster sizing and an optimal buffer clustering policy. Before deriving the 
aforementioned relationships, the notations, assumptions and definitions are listed. Fig. 6 which shows the inventory profile in buffer $B_{i}$ is used to illustrate the new notations $\mathrm{K} 2{ }_{\mathrm{i}}, \mathrm{K} 3_{\mathrm{i}}, \overline{\mathrm{t}}_{1 \mathrm{Bi}}, \overline{\mathrm{t}}_{2 \mathrm{Bi}}$ and $\mathrm{MB} \mathrm{B}_{\mathrm{i}}-1$.

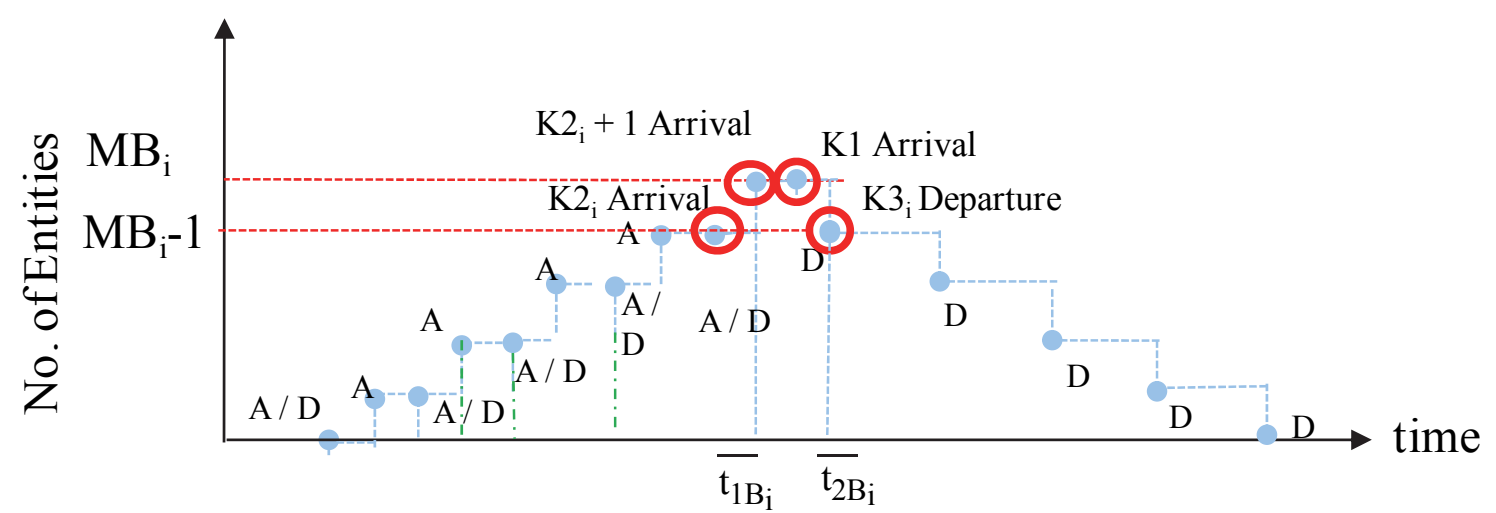

Notations:

Fig. 6. Illustration of $K 2_{i}, K 3_{i}, \bar{t}_{1 B i}, \bar{t}_{2 B i}$ and $M B_{i}-1$

N7) $W_{j}$ is a set of one or more buffers referred to as a buffer cluster.

$\mathrm{N} 8) \mathrm{BB}_{\mathrm{j}}$ is the maximum number of entities a buffer cluster $W_{j}$ must be able to hold to ensure that no overflows or underflows occur in the buffer cluster.

N9) $\mathrm{X}_{\mathrm{j}}$ is a binary variable $\{0,1\}$ and defines whether cluster $W_{j}$ must be realized $\{1\}$ or not $\{0\}$ (i.e. $\mathrm{X}_{\mathrm{j}}$ $=1$ determines that cluster $W_{j}$ must be selected as a part of the buffer cluster policy).

N10) $\mathrm{K} 2{ }_{\mathrm{i}}$ is the last arrival to buffer $B_{i}$ that occurs when the number of entities in buffer $B_{i}$ is $\mathrm{MB}_{\mathrm{i}}-1$

N11) $\mathrm{K} 3_{\mathrm{i}}$ is the number of entities that depart from buffer $\mathrm{B}_{\mathrm{i}}$ changing the number of entities in buffer $B_{i}$ to $\mathrm{MB}_{\mathrm{i}}-1$ from $\mathrm{MB}_{\mathrm{i}}$. This occurs right after the last arrival (K1 arrival) to buffer $B_{i}$.

N12) $\bar{t}_{1 B i}$ is the time of the first arrival changing the number of entities in buffer $B_{i}$ to $M_{i}$ from $M_{i}-$ $1(\mathrm{~K} 2 \mathrm{i}+1$ arrival).

$\mathrm{N} 13) \overline{\mathrm{t}}_{2 \mathrm{Bi}}$ is the time of the first departure (K3 $\left.3_{\mathrm{i}}\right)$ departing after the last arrival (K1 arrival) for buffer $B_{i}$. It is the last time the number of entities in buffer $B_{i}$ equals $\mathrm{MB}_{\mathrm{i}}$.

N14) q is the time the last entity departs from server $S_{N}$ to buffer $B_{N+1}$

$\mathrm{N} 15) \mathrm{H}$ is the size each entity occupies within a cell of a buffer in square meters

N16) $G$ is the maximum size of a buffer cluster $W_{j}$ in square meters

Assumptions: (Assumptions A1 through A8 from part A hold)

A9) Possible combinations (clusters) of buffers are given.

A10) A buffer $B_{i}$ must be either a dedicated buffer or in a single cluster; thus, if $\{2,3, \ldots, i, \ldots, N\}$ denotes the index set of intermediate buffers $\mathrm{B}_{\mathrm{i}}$ and $\{1,2, \ldots j, \ldots, C\}$ the index set of buffer clusters $W_{j}$, then

$$
\bigcup_{j=1}^{c} W_{j}=\{2,3, \ldots, N\}
$$

Although a buffer cluster must maintain the sequence of operations, meaning it must facilitate an entity to move in the sequence of operations from servers $S_{1}, S_{2}, S_{3} \ldots$ to $S_{N}$ the buffers included in a cluster should not necessarily be sequential. Therefore, a buffer cluster may include non-sequential buffers and still maintain the sequence of operations. The example in Fig. 7 shows non-sequential buffers $B_{2}$ and $B_{5}$ clustered $\left(W_{l}\right)$ and sequential buffers $B_{3}$ and $B_{4}$ clustered $\left(W_{2}\right)$ while still maintaining the sequence of operations $S_{1}$ through $S_{5}$ as shown by the arrows. 


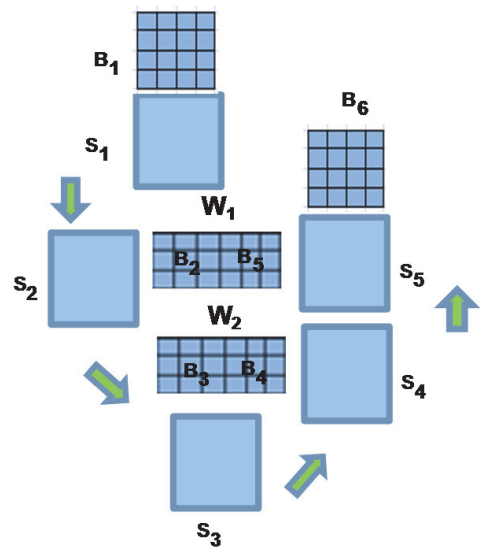

Fig. 7. Non-sequential and sequential buffer clusters maintaining sequence of operations

Eq. (8) in section 3.1 provides us with the maximum number of entities that buffer $B_{i}$ will experience over a given demand $\mathrm{K} 1$ within a production shift and is used for sizing the dedicated buffers to ensure that no overflows or underflows occur. The size required for the buffer cluster combinations is needed at any given time. Thus, for the buffer cluster, the buffer sizes leveraging Eq. (11) are assessed at every given time $t$ as shown in Eq. (12) from the time of first arrival $\left(\tau_{1}\right)$ of an entity in buffer $B_{2}$ to the completion of the production shift (q) (See assumption A6).

$$
\mathrm{B}_{\mathrm{i}}(\mathrm{t})=\min \left(\mathrm{K} 1,1+\left\lfloor\frac{\mathrm{t}-\tau_{\mathrm{i}-1}}{\mathrm{MT} \mathrm{T}_{\mathrm{i}-1}}\right\rfloor\right)-\min \left(\mathrm{K} 1,1-\left\lfloor\frac{\mathrm{t}-\tau_{\mathrm{i}-1}}{\mathrm{MT} \mathrm{T}_{\mathrm{i}}}\right\rfloor\right) \quad \forall \mathrm{t} \in\left[\tau_{\mathrm{i}-1}, \mathrm{q}\right]
$$

From Eq. (12) the search for the buffer cluster size requires a calculation at each time step throughout the production shift for every buffer $B_{i}$. This results in a significant number of computations. Appendix $B$ quantifies how the number of calculations can be substantially reduced. Before quantifying the savings, the authors solve for $\mathrm{BB}_{\mathrm{j}}$. To solve for $\mathrm{BB}_{\mathrm{j}}$, first solve for $\bar{t}_{1 B i}$ and $\bar{t}_{2 B i}$ (see Fig. 6) and then prove that the maximum buffer cluster size required occurs when one of the individual buffers $B_{i}$ is at a maximum during the time interval $t \in\left[\bar{t}_{1 B i}, \bar{t}_{2 B i}\right]$. To solve for $\bar{t}_{1 B i}$, first solve for the last arrival $\left(\mathrm{K} 2{ }_{\mathrm{i}}\right)$ that occurs at $\mathrm{MB}_{\mathrm{i}}-1$. Eq. (8) is modified as shown in Eq. (13).

$$
\mathrm{MB}_{\mathrm{i}}-1=\left(\mathrm{K} 2_{\mathrm{i}}-1\right)-\left\lfloor\mathrm{Y}_{\mathrm{i}}^{*}\left(\mathrm{~K} 2_{\mathrm{i}}-1\right)\right\rfloor
$$

Then to get the first arrival that occurs at $\mathrm{MB}_{\mathrm{i}}$, solve for the time $\bar{t}_{1 B i}$ that the $\mathrm{K} 2_{\mathrm{i}}+1$ arrival arrives to buffer $\mathrm{B}_{\mathrm{i}}$

$$
\overline{\mathrm{t}}_{1 \mathrm{Bi}}=\tau_{\mathrm{i}-1}+\left(\left(\mathrm{K} 2_{\mathrm{i}}+1\right)-1\right) * \mathrm{MT}_{\mathrm{i}-1}
$$

To determine $\bar{t}_{2 B i}$, first solve for the time of the K1th arrival to buffer $B_{i}$ using Eq. (10) and use Eq. (5) to calculate the number of departures that have occurred by the K1th arrival. Then add one to the departures (named $\mathrm{K} 3_{\mathrm{i}}$ ) and calculate the time of this departure $\left(\overline{t_{2 B i}}\right)$ using Eq. (15).

$$
\overline{\mathrm{t}}_{2 \mathrm{Bi}}=\tau_{\mathrm{i}-1}+\left(\mathrm{K} 3_{\mathrm{i}}-1\right) * \mathrm{MT}_{\mathrm{i}}
$$

The minimum size for a cluster $\mathrm{W}_{\mathrm{j}}$ such that no overflows occur is shown in Eq. (16).

$$
\mathrm{BB}_{\mathrm{j}}=\max _{\mathrm{t} \in \cup_{\mathrm{i}=1}^{\mathrm{N}}\left[\overline{\mathrm{t}}_{1 \mathrm{Bi}}, \overline{\mathrm{t}}_{2} \mathrm{Bi}\right]}\left\{\sum_{\mathrm{B}_{\mathrm{r}} \in \mathrm{W}_{\mathrm{j}}} \mathrm{B}_{\mathrm{r}}(\mathrm{t})\right\} \quad \forall \mathrm{W}_{\mathrm{j}}
$$

In Appendix A, the authors prove that the buffer cluster size required occurs when at least one of the individual buffers in the cluster $W_{j}$ is at a maximum according to Eq. (16). Thus the buffer cluster size search in the time domain can be reduced by searching across all buffers only for those time steps when 
a buffer is at a maximum. This results in significant computational savings. The computational savings are calculated for the case study discussed in Section 4 and shown in Appendix B.

For a given production line, there can be hundreds of buffer cluster combinations. Consider a collection of candidate buffer clusters $\mathrm{W}_{\mathrm{j}}, \mathrm{j}=1, \ldots, \mathrm{C}$, not necessarily disjoint, for which the minimum storage requirements $\mathrm{BB}_{\mathrm{j}}$ have been computed via Eq. (16). Integer programming is used to find the buffer cluster combination that provides the minimum total space occupied by all clusters. From here set the objective function as shown in Eq. (17) to determine the buffer cluster(s) size across the production line where $X_{j}$ $\in\{0,1\}$ is a decision variable that determines whether the buffer cluster $W_{j}$ should be realized or not. As defined earlier each buffer can only participate in one and only one realized buffer cluster. The first set of constraints Eq. (18) show that a buffer $B_{i}$ can only participate in one combination buffer cluster. The second set of constraints Eq. (19) is the maximum size of a buffer cluster in square meters. The third set of constraints Eq. (20) is the binary constraints for $\mathrm{X}_{\mathrm{j}} . \mathrm{V}_{\mathrm{j}}$ is defined to ensure constraint Eq. (18) applies only to buffers within cluster $\mathrm{W}_{\mathrm{j}}$.

$\mathrm{V}_{\mathrm{j}}=\left\{i, B_{i} \in W_{j}\right\} \quad 1 \leq \mathrm{j} \leq \mathrm{C}$

Objective Function:

$$
\min \sum_{\mathrm{j}=1}^{\mathrm{C}} \mathrm{BB}_{\mathrm{j}} \mathrm{X}_{\mathrm{j}}
$$

subject to:

$$
\begin{aligned}
& \sum_{j: i \in V_{j}} X_{j}=1,1 \leq \mathrm{i} \leq \mathrm{N} \\
& \mathrm{BB}_{\mathrm{j}} * \mathrm{H}^{*} \mathrm{X}_{\mathrm{j}} \leq \mathrm{G}, \quad 1 \leq \mathrm{j} \leq \mathrm{C} \\
& X_{j}=0 \text { or } 1 \forall \mathrm{j}
\end{aligned}
$$

\section{Applying model to the industry example}

As discussed in the Introduction, the underlying motivation for this research was a case study where a manufacturing facility that produces mobile devices wished to change over from a serial line to a buffer cluster configuration. Table 1 shows the server stations and process times. The footprint for buffer cell holding an entity is $0.005 \mathrm{~m}^{2}$. The maximum buffer cluster size is $1.825 \mathrm{~m}^{2}$.

Table 1

Production line processes

\begin{tabular}{lccccccc}
\hline Element & $S_{1}$ & $S_{2}$ & $S_{3}$ & $S_{4}$ & $S_{5}$ & $S_{6}$ & $S_{7}$ \\
\hline Process Times (Seconds) & 1 & 2 & 4 & 5 & 14 & 10 & 19 \\
\hline
\end{tabular}

Given $B_{1}$ and $B_{8}$ are the starting and ending inventory buffers, these are not included in the analysis. Eq. (8) and Eq. (16) are used to populate Table 2 with $\mathrm{W}_{\mathrm{j}}$ cluster sets and size for buffers $B_{2}$ through $B$ 7. The production line shift is 8 hours and 458 units are projected to ship by the end of the shift. There is a space constraint of 1.825 square meters for the buffer cluster size. In Table 2, the cells with bold text indicate that the cluster does not meet the space constraint (i.e. the buffer cluster size $\mathrm{BB}_{\mathrm{j}}>365$ entities). The objective function according to Eq. (17) and constraints according to Eqs. (18 - 20) are below. As discussed in Section 3.2, a buffer cannot participate in multiple clusters at the same time. Table 3 shows the buffer storage space savings for the top buffer cluster configurations considered by the manufacturing center compared to that of the cluster that does not consider the space constraint and that for dedicated buffers. The manufacturing center desired to leverage the cluster for work cells to minimize the buffer storage space. The top buffer cluster configurations considered by the manufacturing center contained buffer clusters with three or four buffers clustered together. 
Table 2

$\mathrm{W}_{\mathrm{j}}$ Buffer cluster sets and $\mathrm{BB}_{\mathrm{j}}$ values for each buffer cluster set

\begin{tabular}{|c|c|c|c|}
\hline $\mathrm{W}_{1}=\left\{\mathrm{B}_{2}\right\}$ & $\mathrm{W}_{2}=\left\{\mathrm{B}_{3}\right\}$ & $\mathrm{W}_{3}=\left\{\mathrm{B}_{4}\right\}$ & $\mathrm{W}_{4}=\left\{\mathrm{B}_{5}\right\}$ \\
\hline $\mathrm{BB}_{1}=229$ & $\mathrm{BB}_{2}=229$ & $\mathrm{BB}_{3}=92$ & $\mathrm{BB}_{4}=294$ \\
\hline $\mathrm{W}_{5}=\left\{\mathrm{B}_{6}\right\}$ & $\mathrm{W}_{6}=\left\{\mathrm{B}_{7}\right\}$ & $\mathrm{W}_{7}=\left\{\mathrm{B}_{2,} \mathrm{~B}_{3}\right\}$ & $\mathrm{W}_{8}=\left\{\mathrm{B}_{2} \mathrm{~B}_{4}\right\}$ \\
\hline $\mathrm{BB}_{5}=1$ (Transport) & $\mathrm{BB}_{6}=121$ & $\mathrm{BB}_{7}=343$ & $\mathrm{BB}_{8}=251$ \\
\hline $\mathrm{W}_{9}=\left\{\mathrm{B}_{2} \mathrm{~B}_{5}\right\}$ & $\mathrm{W}_{10}=\left\{\mathrm{B}_{2} \mathrm{~B}_{6}\right\}$ & $\mathrm{W}_{11}=\left\{\mathrm{B}_{2,} \mathrm{~B}_{7}\right\}$ & $\mathrm{W}_{12}=\left\{\mathrm{B}_{3} \mathrm{~B}_{4}\right\}$ \\
\hline $\mathrm{BB}_{9}=294$ & $\mathrm{BB}_{10}=230$ & $\mathrm{BB}_{11}=237$ & $\mathrm{BB}_{12}=274$ \\
\hline $\mathrm{W}_{13}=\left\{\mathrm{B}_{3}, \mathrm{~B}_{5}\right\}$ & $\mathrm{W}_{14}=\left\{\mathrm{B}_{3}, \mathrm{~B}_{6}\right\}$ & $\mathrm{W}_{15}=\left\{\mathrm{B}_{3} \mathrm{~B}_{7}\right\}$ & $\mathrm{W}_{16}=\left\{\mathrm{B}_{4}, \mathrm{~B}_{5}\right\}$ \\
\hline $\mathrm{BB}_{13}=346$ & $\mathrm{BB}_{14}=230$ & $\mathrm{BB}_{15}=246$ & $\mathrm{BB}_{16}=326$ \\
\hline $\mathrm{W}_{17}=\left\{\mathrm{B}_{4} \mathrm{~B}_{6}\right\}$ & $\mathrm{W}_{18}=\left\{\mathrm{B}_{4} \mathrm{~B}_{7}\right\}$ & $\mathrm{W}_{19}=\left\{\mathrm{B}_{5} \mathrm{~B}_{6}\right\}$ & $\mathrm{W}_{20}=\left\{\mathrm{B}_{5} \mathrm{~B}_{7}\right\}$ \\
\hline $\mathrm{BB}_{17}=93$ & $\mathrm{BB}_{18}=126$ & $\mathrm{BB}_{19}=295$ & $\mathrm{BB}_{20}=337$ \\
\hline $\mathrm{W}_{21}=\left\{\mathrm{B}_{6}, \mathrm{~B}_{7}\right\}$ & $\mathrm{W}_{22}=\left\{\mathrm{B}_{2}, \mathrm{~B}_{3}, \mathrm{~B}_{4}\right\}$ & $\mathbf{W}_{23}=\left\{\mathbf{B}_{2}, \mathbf{B}_{3}, \mathbf{B}_{5}\right\}$ & $\mathrm{W}_{24}=\left\{\mathrm{B}_{2}, \mathrm{~B}_{3}, \mathrm{~B}_{6}\right\}$ \\
\hline $\mathrm{BB}_{21}=122$ & $\mathrm{BB}_{22}=365$ & $\mathrm{BB}_{23}=401$ & $\mathrm{BB}_{24}=344$ \\
\hline $\mathrm{W}_{25}=\left\{\mathrm{B}_{2,} \mathrm{~B}_{3,} \mathrm{~B}_{7}\right\}$ & $\mathrm{W}_{26}=\left\{\mathrm{B}_{2}, \mathrm{~B}_{4,} \mathrm{~B}_{5}\right\}$ & $\mathrm{W}_{27}=\left\{\mathrm{B}_{2,} \mathrm{~B}_{4,} \mathrm{~B}_{6}\right\}$ & $\mathrm{W}_{28}^{24}=\left\{\mathrm{B}_{2,} \mathrm{~B}_{4}, \mathrm{~B}_{7}\right\}$ \\
\hline $\mathrm{BB}_{25}=351$ & $\mathrm{BB}_{26}=326$ & $\mathrm{BB}_{27}=252$ & $\mathrm{BB}_{28}=259$ \\
\hline $\mathrm{W}_{29}=\left\{\mathrm{B}_{2,} \mathrm{~B}_{5} \mathrm{~B}_{6}\right\}$ & $\mathrm{W}_{30}=\left\{\mathrm{B}_{2}, \mathrm{~B}_{5} \mathrm{~B}_{7}\right\}$ & $\mathrm{W}_{31}=\left\{\mathrm{B}_{2}, \mathrm{~B}_{6}, \mathrm{~B}_{7}\right\}$ & $\mathbf{W}_{32}=\left\{\mathbf{B}_{3}, \mathbf{B}_{4}, \mathbf{B}_{5}\right\}$ \\
\hline $\mathrm{BB}_{29}=295$ & $\mathrm{BB}_{30}=337$ & $\mathrm{BB}_{31}=238$ & $\mathrm{BB}_{32}=391$ \\
\hline $\mathrm{W}_{33}=\left\{\mathrm{B}_{3}, \mathrm{~B}_{4} \mathrm{~B}_{6}\right\}$ & $\mathrm{W}_{34}=\left\{\mathrm{B}_{3}, \mathrm{~B}_{4} \mathrm{~B}_{7}\right\}$ & $\mathrm{W}_{35}=\left\{\mathrm{B}_{3}, \mathrm{~B}_{5}, \mathrm{~B}_{6}\right\}$ & $\mathrm{W}_{36}=\left\{\mathrm{B}_{3}, \mathrm{~B}_{5}, \mathrm{~B}_{7}\right\}$ \\
\hline $\mathrm{BB}_{33}=275$ & $\mathrm{BB}_{34}=291$ & $\mathrm{BB}_{35}=347$ & $\mathrm{BB}_{36}=363$ \\
\hline $\mathrm{W}_{37}=\left\{\mathrm{B}_{3,}, \mathrm{~B}_{6}, \mathrm{~B}_{7}\right\}$ & $\mathrm{W}_{38}=\left\{\mathrm{B}_{4}, \mathrm{~B}_{5}, \mathrm{~B}_{6}\right\}$ & $\mathrm{W}_{39}=\left\{\mathrm{B}_{4,} \mathrm{~B}_{5} \mathrm{~B}_{7}\right\}$ & $\mathrm{W}_{40}=\left\{\mathrm{B}_{4}, \mathrm{~B}_{6}, \mathrm{~B}_{7}\right\}$ \\
\hline $\mathrm{BB}_{37}=247$ & $\mathrm{BB}_{38}=327$ & $\mathrm{BB}_{39}=360$ & $\mathrm{BB}_{40}=127$ \\
\hline $\mathrm{W}_{41}=\left\{\mathrm{B}_{5}, \mathrm{~B}_{6}, \mathrm{~B}_{7}\right\}$ & $\mathbf{W}_{42}=\left\{\mathbf{B}_{2}, \mathbf{B}_{3}, \mathbf{B}_{4}, \mathbf{B}_{5}\right\}$ & $\mathbf{W}_{43}=\left\{\mathbf{B}_{2}, \mathbf{B}_{3}, \mathbf{B}_{4}, \mathbf{B}_{6}\right\}$ & $\mathbf{W}_{44}=\left\{\mathbf{B}_{2}, \mathbf{B}_{3}, \mathbf{B}_{4}, \mathbf{B}_{7}\right\}$ \\
\hline $\mathrm{BB}_{41}=338$ & $\mathrm{BB}_{42}=423$ & $\mathrm{BB}_{43}=366$ & $\mathrm{BB}_{44}=373$ \\
\hline $\mathbf{W}_{45}=\left\{\mathbf{B}_{2}, \mathbf{B}_{3}, \mathbf{B}_{5}, \mathbf{B}_{6}\right\}$ & $\mathbf{W}_{46}=\left\{\mathbf{B}_{2}, \mathbf{B}_{3}, \mathbf{B}_{5}, \mathbf{B}_{7}\right\}$ & $\mathrm{W}_{47}=\left\{\mathrm{B}_{2}, \mathrm{~B}_{3}, \mathrm{~B}_{6}, \mathrm{~B}_{7}\right\}$ & $\mathrm{W}_{48}=\left\{\mathrm{B}_{2,} \mathrm{~B}_{4} \mathrm{~B}_{5}, \mathrm{~B}_{6}\right\}$ \\
\hline $\mathbf{B B}_{45}=\mathbf{4 0 2}$ & $\mathrm{BB}_{46}=409$ & $\mathrm{BB}_{47}=352$ & $\mathrm{BB}_{48}=327$ \\
\hline $\mathrm{W}_{49}=\left\{\mathrm{B}_{2}, \mathrm{~B}_{4}, \mathrm{~B}_{5}, \mathrm{~B}_{7}\right\}$ & $\mathrm{W}_{50}=\left\{\mathrm{B}_{2}, \mathrm{~B}_{4}, \mathrm{~B}_{6}, \mathrm{~B}_{7}\right\}$ & $\mathrm{W}_{51}=\left\{\mathrm{B}_{2,} \mathrm{~B}_{5}, \mathrm{~B}_{6}, \mathrm{~B}_{7}\right\}$ & $\mathbf{W}_{52}=\left\{\mathbf{B}_{3}, \mathbf{B}_{4}, \mathbf{B}_{5}, \mathbf{B}_{6}\right\}$ \\
\hline $\mathrm{BB}_{49}=360$ & $\mathrm{BB}_{50}=260$ & $\mathrm{BB}_{51}=338$ & $\mathrm{BB}_{52}=392$ \\
\hline $\mathbf{W}_{53}=\left\{\mathbf{B}_{3}, \mathbf{B}_{4}, \mathbf{B}_{5}, \mathbf{B}_{7}\right\}$ & $\mathrm{W}_{54}=\left\{\mathrm{B}_{3}, \mathrm{~B}_{4}, \mathrm{~B}_{6}, \mathrm{~B}_{7}\right\}$ & $\mathrm{W}_{55}=\left\{\mathrm{B}_{3,} \mathrm{~B}_{5}, \mathrm{~B}_{6}, \mathrm{~B}_{7}\right\}$ & $\mathrm{W}_{56}=\left\{\mathrm{B}_{4,} \mathrm{~B}_{5,} \mathrm{~B}_{6}, \mathrm{~B}_{7}\right\}$ \\
\hline $\mathrm{BB}_{53}=408$ & $\mathrm{BB}_{54}=292$ & $\mathrm{BB}_{55}=364$ & $\mathrm{BB}_{56}=361$ \\
\hline $\mathbf{W}_{57}=\left\{\mathbf{B}_{2}, \mathbf{B}_{3}, \mathbf{B}_{4}, \mathbf{B}_{5} \mathbf{B}_{6}\right\}$ & $\mathbf{W}_{58}=\left\{\mathbf{B}_{2}, \mathbf{B}_{3}, \mathbf{B}_{4}, \mathbf{B}_{5}, \mathbf{B}_{7}\right\}$ & $\mathbf{W}_{59}=\left\{\mathbf{B}_{2}, \mathbf{B}_{3}, \mathbf{B}_{4}, \mathbf{B}_{6}, \mathbf{B}_{7}\right\}$ & $\mathbf{W}_{60}=\left\{\mathbf{B}_{2}, \mathbf{B}_{3}, \mathbf{B}_{5}, \mathbf{B}_{6}, \mathbf{B}_{7}\right\}$ \\
\hline $\mathrm{BB}_{57}=424$ & $\mathrm{BB}_{58}=431$ & $\mathrm{BB}_{59}=374$ & $B B_{60}=410$ \\
\hline $\mathrm{W}_{61}=\left\{\mathrm{B}_{2}, \mathrm{~B}_{4,} \mathrm{~B}_{5} \mathrm{~B}_{6} \mathrm{~B}_{7}\right\}$ & $\mathbf{W}_{62}=\left\{\mathbf{B}_{3}, \mathbf{B}_{4}, \mathbf{B}_{5}, \mathbf{B}_{6}, \mathbf{B}_{7}\right\}$ & $\mathbf{W}_{63}=\left\{\mathbf{B}_{2}, \mathbf{B}_{3}, \mathbf{B}_{4}, \mathbf{B}_{5}, \mathbf{B}_{6}, \mathbf{B}_{7}\right\}$ & \\
\hline $\mathrm{BB}_{61}=361$ & $\mathrm{BB}_{62}=409$ & $\mathrm{BB}_{63}=432$ & \\
\hline
\end{tabular}

\section{Objective Function}

$\min \sum_{\mathrm{i}=1}^{63} \mathrm{BB}_{\mathrm{j}}^{*} \mathrm{X}_{\mathrm{j}}$

subject to:

Constraint for $B_{2}$ :

$\mathrm{X}_{1}+\mathrm{X}_{7}+\mathrm{X}_{8}+\mathrm{X}_{9}+\mathrm{X}_{10}+\mathrm{X}_{11}+\mathrm{X}_{22}+\mathrm{X}_{23}+\mathrm{X}_{24}+\mathrm{X}_{25}+\mathrm{X}_{26}+\mathrm{X}_{27}+\mathrm{X}_{28}+\mathrm{X}_{29}+\mathrm{X}_{30}+\mathrm{X}_{31}+\mathrm{X}_{42}+\mathrm{X}_{43}$

$+\mathrm{X}_{44}+\mathrm{X}_{45}+\mathrm{X}_{46}+\mathrm{X}_{47}+\mathrm{X}_{48}+\mathrm{X}_{49}+\mathrm{X}_{50}+\mathrm{X}_{51}+\mathrm{X}_{57}+\mathrm{X}_{58}+\mathrm{X}_{59}+\mathrm{X}_{60}+\mathrm{X}_{61}+\mathrm{X}_{63}=1$

Constraint for $B_{3}$ :

$\mathrm{X} 2+\mathrm{X} 7+\mathrm{X} 12+\mathrm{X} 13+\mathrm{X} 14+\mathrm{X} 15+\mathrm{X} 22+\mathrm{X} 23+\mathrm{X} 24+\mathrm{X} 25+\mathrm{X} 32+\mathrm{X} 33+\mathrm{X} 34+\mathrm{X} 35+\mathrm{X} 36+\mathrm{X} 37+\mathrm{X} 42+$

$\mathrm{X} 43+\mathrm{X} 44+\mathrm{X} 45+\mathrm{X} 46+\mathrm{X} 47+\mathrm{X} 52+\mathrm{X} 53+\mathrm{X} 54+\mathrm{X} 55+\mathrm{X} 57+\mathrm{X} 58+\mathrm{X} 59+\mathrm{X} 60+\mathrm{X} 62+\mathrm{X} 63=1$

Constraint for $B_{4}$ :

$\mathrm{X} 3+\mathrm{X} 8+\mathrm{X} 12+\mathrm{X} 16+\mathrm{X} 17+\mathrm{X} 18+\mathrm{X} 22+\mathrm{X} 26+\mathrm{X} 27+\mathrm{X} 28+\mathrm{X} 32+\mathrm{X} 33+\mathrm{X} 34+\mathrm{X} 38+\mathrm{X} 39+\mathrm{X} 40+\mathrm{X} 42+\mathrm{X} 43$

$+\mathrm{X} 44+\mathrm{X} 48+\mathrm{X} 49+\mathrm{X} 50+\mathrm{X} 52+\mathrm{X} 53+\mathrm{X} 54+\mathrm{X} 56+\mathrm{X} 57+\mathrm{X} 58+\mathrm{X} 59+\mathrm{X} 61+\mathrm{X} 62+\mathrm{X} 63=1$ 
Constraint for $B_{5}$ :

$\mathrm{X} 4+\mathrm{X} 9+\mathrm{X} 13+\mathrm{X} 16+\mathrm{X} 19+\mathrm{X} 20+\mathrm{X} 23+\mathrm{X} 26+\mathrm{X} 29+\mathrm{X} 30+\mathrm{X} 32+\mathrm{X} 35+\mathrm{X} 36+\mathrm{X} 38+\mathrm{X} 39+\mathrm{X} 41+\mathrm{X} 42+$

$\mathrm{X} 45+\mathrm{X} 46+\mathrm{X} 48+\mathrm{X} 49+\mathrm{X} 51+\mathrm{X} 52+\mathrm{X} 53+\mathrm{X} 55+\mathrm{X} 56+\mathrm{X} 57+\mathrm{X} 58+\mathrm{X} 60+\mathrm{X} 61+\mathrm{X} 62+\mathrm{X} 63=1$

Constraint for B6:

$\mathrm{X} 5+\mathrm{X} 10+\mathrm{X} 14+\mathrm{X} 17+\mathrm{X} 19+\mathrm{X} 21+\mathrm{X} 24+\mathrm{X} 27+\mathrm{X} 29+\mathrm{X} 31+\mathrm{X} 33+\mathrm{X} 35+\mathrm{X} 37+\mathrm{X} 38+\mathrm{X} 40+\mathrm{X} 41+\mathrm{X} 43+$

$\mathrm{X} 45+\mathrm{X} 47+\mathrm{X} 48+\mathrm{X} 50+\mathrm{X} 51+\mathrm{X} 52+\mathrm{X} 54+\mathrm{X} 55+\mathrm{X} 56+\mathrm{X} 57+\mathrm{X} 59+\mathrm{X} 60+\mathrm{X} 61+\mathrm{X} 62+\mathrm{X} 63=1$

Constraint for B7:

$\mathrm{X} 6+\mathrm{X} 11+\mathrm{X} 15+\mathrm{X} 18+\mathrm{X} 20+\mathrm{X} 21+\mathrm{X} 25+\mathrm{X} 28+\mathrm{X} 30+\mathrm{X} 31+\mathrm{X} 34+\mathrm{X} 36+\mathrm{X} 37+\mathrm{X} 39+\mathrm{X} 40+\mathrm{X} 41+\mathrm{X} 44+$

$\mathrm{X} 46+\mathrm{X} 47+\mathrm{X} 49+\mathrm{X} 50+\mathrm{X} 51+\mathrm{X} 53+\mathrm{X} 54+\mathrm{X} 55+\mathrm{X} 56+\mathrm{X} 58+\mathrm{X} 59+\mathrm{X} 60+\mathrm{X} 61+\mathrm{X} 62+\mathrm{X} 63=1$

Space Constraints $\mathrm{BB}_{\mathrm{j}}{ }^{*} 0.005^{*} \mathrm{X}_{\mathrm{j}} \leq 1.825,1 \leq \mathrm{j} \leq 63$

Binary Constraint: $X_{j}=0$ or 1

Fig. 8 (part a) is the original production line configuration. Batches of 80 come from inventory and enter the production line $\left(\mathrm{B}_{1}\right)$. Batches of 80 are put on a pallet and shipped $\left(\mathrm{B}_{8}\right)$. The top cluster configurations considered by the facility based on buffer storage savings were then entered into a facility layout tool. The configuration shown in Fig. 8 (part b) was selected $\left\{\mathrm{B}_{3}, \mathrm{~B}_{4}, \mathrm{~B}_{7}\right\},\left\{\mathrm{B}_{2}, \mathrm{~B}_{5}, \mathrm{~B}_{6}\right\}$ resulting in a $39.3 \%$ buffer storage savings (1.9 square meters).

Table 3

Buffer cluster sets and buffer storage savings

\begin{tabular}{|c|c|c|c|c|}
\hline Cluster Set & $\begin{array}{c}\text { Size } \\
\text { (No. Entities) } \\
\end{array}$ & $\begin{array}{l}\text { Size } \\
\left(\mathrm{m}^{2}\right)\end{array}$ & $\begin{array}{c}\text { Buffer Storage Space } \\
\text { Savings }\left(\mathrm{m}^{2}\right) \\
\end{array}$ & Space Savings \% \\
\hline$\left\{\mathrm{B}_{2}\right\},\left\{\mathrm{B}_{3}\right\},\left\{\mathrm{B}_{4}\right\},\left\{\mathrm{B}_{5}\right\},\left\{\mathrm{B}_{6}\right\},\left\{\mathrm{B}_{7}\right\}^{*}$ & 966 & 4.83 & & \\
\hline$\left\{\mathrm{B}_{2}, \mathrm{~B}_{3}, \mathrm{~B}_{4}, \mathrm{~B}_{5}, \mathrm{~B}_{6}, \mathrm{~B}_{7}\right\} * *$ & 432 & 2.16 & 2.67 & $55.3 \%$ \\
\hline$\left\{\mathrm{B}_{2,} \mathrm{~B}_{4}, \mathrm{~B}_{5}, \mathrm{~B}_{6}, \mathrm{~B}_{7}\right\},\left\{\mathrm{B}_{3}\right\}$ & 590 & 2.95 & 1.88 & $38.9 \%$ \\
\hline$\left\{\mathrm{B}_{2}, \mathrm{~B}_{5}, \mathrm{~B}_{6}, \mathrm{~B}_{7}\right\},\left\{\mathrm{B}_{3}, \mathrm{~B}_{4}\right\}$ & 612 & 3.06 & 1.77 & $36.7 \%$ \\
\hline$\left\{\mathrm{B}_{3}, \mathrm{~B}_{5}, \mathrm{~B}_{6}, \mathrm{~B}_{7}\right\},\left\{\mathrm{B}_{2}, \mathrm{~B}_{4}\right\}$ & 615 & 3.08 & 1.76 & $36.3 \%$ \\
\hline$\left\{\mathrm{B}_{3}, \mathrm{~B}_{4}, \mathrm{~B}_{6}, \mathrm{~B}_{7}\right\},\left\{\mathrm{B}_{2}, \mathrm{~B}_{5}\right\}$ & 586 & 2.93 & 1.90 & $39.3 \%$ \\
\hline$\left\{\mathrm{B}_{2}, \mathrm{~B}_{4}, \mathrm{~B}_{5}, \mathrm{~B}_{6}\right\},\left\{\mathrm{B}_{3}, \mathrm{~B}_{7}\right\}$ & 573 & 2.87 & 1.97 & $40.7 \%$ \\
\hline$\left\{\mathrm{B}_{2}, \mathrm{~B}_{4}, \mathrm{~B}_{6}, \mathrm{~B}_{7}\right\},\left\{\mathrm{B}_{3}, \mathrm{~B}_{5}\right\}$ & 606 & 3.03 & 1.80 & $37.3 \%$ \\
\hline$\left\{\mathrm{B}_{3}, \mathrm{~B}_{5}, \mathrm{~B}_{7}\right\},\left\{\mathrm{B}_{2}, \mathrm{~B}_{4}, \mathrm{~B}_{6}\right\}$ & 615 & 3.08 & 1.76 & $36.3 \%$ \\
\hline$\left\{\mathrm{B}_{3}, \mathrm{~B}_{5}, \mathrm{~B}_{7}\right\},\left\{\mathrm{B}_{6}\right\},\left\{\mathrm{B}_{2}, \mathrm{~B}_{4}\right\}$ & 615 & 3.08 & 1.76 & $36.3 \%$ \\
\hline$\left\{\mathrm{B}_{3}, \mathrm{~B}_{4}, \mathrm{~B}_{7}\right\},\left\{\mathrm{B}_{2}, \mathrm{~B}_{5}, \mathrm{~B}_{6}\right\}$ & 586 & 2.93 & 1.90 & $39.3 \%$ \\
\hline$\left\{\mathrm{B}_{3}, \mathrm{~B}_{4}, \mathrm{~B}_{7}\right\},\left\{\mathrm{B}_{6}\right\},\left\{\mathrm{B}_{2}, \mathrm{~B}_{5}\right\}$ & 586 & 2.93 & 1.90 & $39.3 \%$ \\
\hline$\left\{\mathrm{B}_{3}, \mathrm{~B}_{4}, \mathrm{~B}_{6}\right\},\left\{\mathrm{B}_{2}, \mathrm{~B}_{5}, \mathrm{~B}_{7}\right\}$ & 612 & 3.06 & 1.77 & $36.6 \%$ \\
\hline$\left\{\mathrm{B}_{2}, \mathrm{~B}_{5}, \mathrm{~B}_{7}\right\},\left\{\mathrm{B}_{6}\right\},\left\{\mathrm{B}_{3}, \mathrm{~B}_{4}\right\}$ & 612 & 3.06 & 1.77 & $36.6 \%$ \\
\hline$\left\{\mathrm{B}_{2}, \mathrm{~B}_{4}, \mathrm{~B}_{5}\right\},\left\{\mathrm{B}_{6}\right\},\left\{\mathrm{B}_{3}, \mathrm{~B}_{7}\right\}$ & 573 & 2.87 & 1.97 & $40.7 \%$ \\
\hline
\end{tabular}

*Dedicated Buffers

** Optimal Buffer Cluster without space constraints 


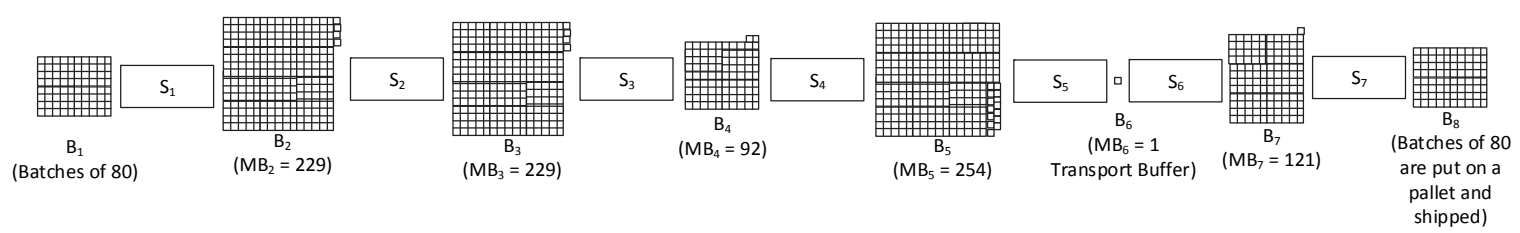

Fig. 8(a). Serial production line

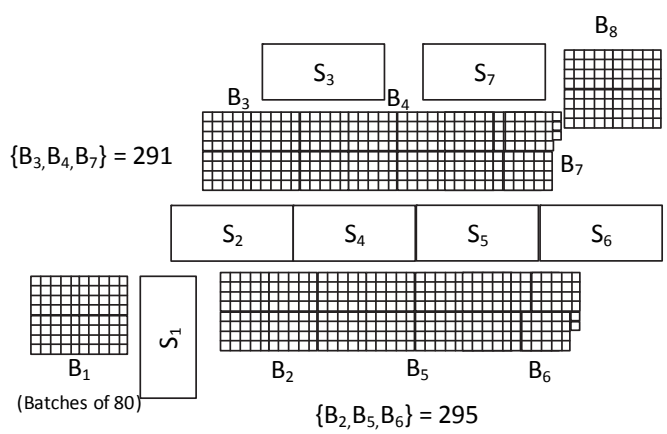

Fig. 8(b). Production line with buffer clusters

As discussed in the introduction, Eq. (16) along with the objective function and constraints in Eqs. (1820) can be used to conduct sensitivity analysis of the buffer cluster size by varying parameters such as server process time $\mathrm{T}_{\mathrm{i}}$ and production demand $\mathrm{K} 1$.

Table 4

$W_{j}$ buffer cluster sets and $B B_{j}$ values for each buffer cluster set $\left(T_{2}=3 s\right)$

\begin{tabular}{|c|c|c|c|}
\hline $\mathrm{W}_{1}=\left\{\mathrm{B}_{2}\right\}$ & $\mathrm{W}_{2}=\left\{\mathrm{B}_{3}\right\}$ & $\mathrm{W}_{3}=\left\{\mathrm{B}_{4}\right\}$ & $\mathrm{W}_{4}=\left\{\mathrm{B}_{5}\right\}$ \\
\hline $\mathrm{BB}_{1}=305$ & $\mathrm{BB}_{2}=115$ & $\mathrm{BB}_{3}=92$ & $\mathrm{BB}_{4}=294$ \\
\hline $\mathrm{W}_{5}=\left\{\mathrm{B}_{6}\right\}$ & $\mathrm{W}_{6}=\left\{\mathrm{B}_{7}\right\}$ & $\mathrm{W}_{7}=\left\{\mathrm{B}_{2,} \mathrm{~B}_{3}\right\}$ & $\mathrm{W}_{8}=\left\{\mathrm{B}_{2 .} \mathrm{B}_{4}\right\}$ \\
\hline $\mathrm{BB}_{5}=1$ (Transport) & $\mathrm{BB}_{6}=121$ & $\mathrm{BB}_{7}=343$ & $\mathrm{BB}_{8}=327$ \\
\hline $\mathrm{W}_{9}=\left\{\mathrm{B}_{2,} \mathrm{~B}_{5}\right\}$ & $\mathrm{W}_{10}=\left\{\mathrm{B}_{2,} \mathrm{~B}_{6}\right\}$ & $\mathrm{W}_{11}=\left\{\mathrm{B}_{2,} \mathrm{~B}_{7}\right\}$ & $\mathrm{W}_{12}=\left\{\mathrm{B}_{3,} \mathrm{~B}_{4}\right\}$ \\
\hline $\mathrm{BB}_{9}=363$ & $\mathrm{BB}_{10}=306$ & $\mathrm{BB}_{11}=313$ & $\mathrm{BB}_{12}=183$ \\
\hline $\mathrm{W}_{13}=\left\{\mathrm{B}_{3} \mathrm{~B}_{5}\right\}$ & $\mathrm{W}_{14}=\left\{\mathrm{B}_{3} \mathrm{~B}_{6}\right\}$ & $\mathrm{W}_{15}=\left\{\mathrm{B}_{3} \mathrm{~B}_{7}\right\}$ & $\mathrm{W}_{16}=\left\{\mathrm{B}_{4} \mathrm{~B}_{5}\right\}$ \\
\hline $\mathrm{BB}_{13}=294$ & $\mathrm{BB}_{14}=116$ & $\mathrm{BB}_{15}=140$ & $\mathrm{BB}_{16}=326$ \\
\hline $\mathrm{W}_{17}=\left\{\mathrm{B}_{4,6} \mathrm{~B}_{6}\right\}$ & $\mathrm{W}_{18}^{14}=\left\{\mathrm{B}_{4,} \mathrm{~B}_{7}\right\}$ & $\mathrm{W}_{19}=\left\{\mathrm{B}_{5} \mathrm{~B}_{6}\right\}$ & $\mathrm{W}_{20}=\left\{\mathrm{B}_{5} \mathrm{~B}_{7}\right\}$ \\
\hline $\mathrm{BB}_{17}=93$ & $\mathrm{BB}_{18}=126$ & $\mathrm{BB}_{19}=295$ & $\mathrm{BB}_{20}=337$ \\
\hline $\mathrm{W}_{21}=\left\{\mathrm{B}_{6,} \mathrm{~B}_{7}\right\}$ & $\mathrm{W}_{22}=\left\{\mathrm{B}_{2,} \mathrm{~B}_{3,} \mathrm{~B}_{4}\right\}$ & $\mathbf{W}_{23}=\left\{\mathbf{B}_{2,} \mathbf{B}_{3}, \mathbf{B}_{5}\right\}$ & $\mathrm{W}_{24}=\left\{\mathrm{B}_{2}, \mathrm{~B}_{3}, \mathrm{~B}_{6}\right\}$ \\
\hline $\mathrm{BB}_{21}=122$ & $\mathrm{BB}_{22}=365$ & $\mathrm{BB}_{23}=401$ & $\mathrm{BB}_{24}=344$ \\
\hline $\mathrm{W}_{25}=\left\{\mathrm{B}_{2,} \mathrm{~B}_{3,} \mathrm{~B}_{7}\right\}$ & $W_{26}=\left\{B_{2,4} B_{4,} B_{5}\right\}$ & $\mathrm{W}_{27}=\left\{\mathrm{B}_{2,} \mathrm{~B}_{4,} \mathrm{~B}_{6}\right\}$ & $\mathrm{W}_{28}=\left\{\mathrm{B}_{2,4} \mathrm{~B}_{4,} \mathrm{~B}_{7}\right\}$ \\
\hline $\mathrm{BB}_{25}=351$ & $B B_{26}=385$ & $\mathrm{BB}_{27}=328$ & $\mathrm{BB}_{28}=335$ \\
\hline $\mathrm{W}_{29}=\left\{\mathrm{B}_{2,} \mathrm{~B}_{5}, \mathrm{~B}_{6}\right\}$ & $W_{30}=\left\{B_{2,} B_{5,} B_{7}\right\}$ & $\mathrm{W}_{31}=\left\{\mathrm{B}_{2,} \mathrm{~B}_{6,} \mathrm{~B}_{7}\right\}$ & $* \mathrm{~W}_{32}=\left\{\mathrm{B}_{3,4} \mathrm{~B}_{4,} \mathrm{~B}_{5}\right\}$ \\
\hline $\mathrm{BB}_{29}=364$ & $B B_{30}=371$ & $\mathrm{BB}_{31}=314$ & $* \mathrm{BB}_{32}=358$ \\
\hline $\mathrm{W}_{33}=\left\{\mathrm{B}_{3,4} \mathrm{~B}_{4,} \mathrm{~B}_{6}\right\}$ & $\mathrm{W}_{34}=\left\{\mathrm{B}_{3}, \mathrm{~B}_{4}, \mathrm{~B}_{7}\right\}$ & $\mathrm{W}_{35}=\left\{\mathrm{B}_{3,} \mathrm{~B}_{5}, \mathrm{~B}_{6}\right\}$ & $\mathrm{W}_{36}=\left\{\mathrm{B}_{3,} \mathrm{~B}_{5,} \mathrm{~B}_{7}\right\}$ \\
\hline $\mathrm{BB}_{33}=184$ & $\mathrm{BB}_{34}=208$ & $\mathrm{BB}_{35}=295$ & $\mathrm{BB}_{36}=337$ \\
\hline $\mathrm{W}_{37}=\left\{\mathrm{B}_{3,}, \mathrm{~B}_{6,} \mathrm{~B}_{7}\right\}$ & $\mathrm{W}_{38}=\left\{\mathrm{B}_{4,} \mathrm{~B}_{5}, \mathrm{~B}_{6}\right\}$ & $\mathrm{W}_{39}=\left\{\mathrm{B}_{4,} \mathrm{~B}_{5}, \mathrm{~B}_{7}\right\}$ & $\mathrm{W}_{40}=\left\{\mathrm{B}_{4,} \mathrm{~B}_{6} \mathrm{~B}_{7}\right\}$ \\
\hline $\mathrm{BB}_{37}=141$ & $\mathrm{BB}_{38}=327$ & $\mathrm{BB}_{39}=360$ & $\mathrm{BB}_{40}=127$ \\
\hline $\mathrm{W}_{41}=\left\{\mathrm{B}_{5}, \mathrm{~B}_{6}, \mathrm{~B}_{7}\right\}$ & $\mathbf{W}_{42}=\left\{\mathbf{B}_{2}, \mathbf{B}_{3}, \mathbf{B}_{4}, \mathbf{B}_{5}\right\}$ & $W_{43}=\left\{B_{2}, B_{3}, B_{4}, B_{6}\right\}$ & $\mathbf{W}_{44}=\left\{\mathbf{B}_{2}, \mathbf{B}_{3}, \mathbf{B}_{4}, \mathbf{B}_{7}\right\}$ \\
\hline $\mathrm{BB}_{41}=338$ & $\mathrm{BB}_{42}=423$ & $\mathrm{BB}_{43}=366$ & $\mathrm{BB}_{44}=373$ \\
\hline $\mathbf{W}_{45}=\left\{\mathbf{B}_{2}, \mathbf{B}_{3}, \mathbf{B}_{5}, \mathbf{B}_{6}\right\}$ & $\mathbf{W}_{46}=\left\{\mathbf{B}_{2}, \mathbf{B}_{3}, \mathbf{B}_{5}, \mathbf{B}_{7}\right\}$ & $\mathrm{W}_{47}=\left\{\mathrm{B}_{2}, \mathrm{~B}_{3}, \mathrm{~B}_{6,} \mathrm{~B}_{7}\right\}$ & $W_{48}=\left\{B_{2}, B_{4}, B_{5}, B_{6}\right\}$ \\
\hline $\mathrm{BB}_{45}=402$ & $\mathrm{BB}_{46}=409$ & $\mathrm{BB}_{47}=352$ & $B B_{48}=386$ \\
\hline$W_{49}=\left\{B_{2,} B_{4,} B_{5}, B_{7}\right\}$ & $\mathrm{W}_{50}=\left\{\begin{array}{llll}\mathrm{B}_{2}, \mathrm{~B}_{4}, & \mathrm{~B}_{6} & \mathrm{~B}_{7}\end{array}\right\}$ & $W_{5 I}=\left\{B_{2} B_{5}, B_{6} B_{7}\right\}$ & $* \mathrm{~W}_{52}^{* 0}=\left\{\mathrm{B}_{3,}, \mathrm{~B}_{4}, \mathrm{~B}_{5}, \mathrm{~B}_{6}\right\}$ \\
\hline$B B_{49}=393$ & $\mathrm{BB}_{50}=336$ & $B B_{51}=372$ & $* \mathrm{BB}_{52}=359$ \\
\hline $\mathbf{W}_{53}=\left\{\mathbf{B}_{3}, \mathbf{B}_{4}, \mathbf{B}_{5}, \mathbf{B}_{7}\right\}$ & $\mathrm{W}_{54}=\left\{\mathrm{B}_{3}, \mathrm{~B}_{4}, \mathrm{~B}_{6} \mathrm{~B}_{7}\right\}$ & $\mathrm{W}_{55}=\left\{\mathrm{B}_{3}, \mathrm{~B}_{5}, \mathrm{~B}_{6,} \mathrm{~B}_{7}\right\}$ & $\mathrm{W}_{56}=\left\{\mathrm{B}_{4,} \mathrm{~B}_{5}, \mathrm{~B}_{6} \mathrm{~B}_{7}\right\}$ \\
\hline $\mathrm{BB}_{53}=384$ & $\mathrm{BB}_{54}=209$ & $\mathrm{BB}_{55}=338$ & $\mathrm{BB}_{56}=361$ \\
\hline$W_{57}=\left\{B_{2}, B_{3}, B_{4}, B_{5}, B_{6}\right\}$ & $\mathbf{W}_{58}=\left\{\mathbf{B}_{2,} \mathbf{B}_{3}, \mathbf{B}_{4}, \mathbf{B}_{5}, \mathbf{B}_{7}\right\}$ & $\mathbf{W}_{59}=\left\{\mathbf{B}_{2}, \mathbf{B}_{3}, \mathbf{B}_{4}, \mathbf{B}_{6} \mathbf{B}_{7}\right\}$ & $\mathbf{W}_{60}=\left\{\mathbf{B}_{2}, \mathbf{B}_{3}, \mathbf{B}_{5}, \mathbf{B}_{6} \mathbf{B}_{7}\right\}$ \\
\hline $\mathrm{BB}_{57}=424$ & $\mathrm{BB}_{58}=431$ & $\mathrm{BB}_{59}=374$ & $\mathrm{BB}_{60}=410$ \\
\hline$W_{61}=\left\{B_{2}, B_{4}, B_{5}, B_{6} B_{7}\right\}$ & $\mathbf{W}_{62}=\left\{\mathbf{B}_{3}, \mathbf{B}_{4}, \mathbf{B}_{5}, \mathbf{B}_{6}, \mathbf{B}_{7}\right\}$ & $\mathbf{W}_{63}=\left\{\mathbf{B}_{2}, \mathbf{B}_{3}, \mathbf{B}_{4}, \mathbf{B}_{5}, \mathbf{B}_{6} \mathbf{B}_{7}\right\}$ & \\
\hline$B B_{61}=394$ & $\mathrm{BB}_{62}=385$ & $\mathrm{BB}_{63}=432$ & \\
\hline
\end{tabular}


Now the authors leverage the framework of the model and vary the process time of one server to demonstrate how the model can be used for sensitivity analysis. In this case, authors vary the process time of server $\mathrm{S}_{2}$ to three seconds, calculate the $\mathrm{BB}_{\mathrm{j}}$ values for each cluster set and show the buffer cluster sets in Table 4. As before, the cells with bold text indicate that the cluster does not meet the space constraint and are the same cells that did not meet the space constraint in Table 2. If the cells are in italicized text, they used to meet the space constraint, but due to the change in the process times, no longer meet the constraint. The cells with a "*" indicate that the cluster exceeded space constraint in Table 2, but now meets the constraint in Table 4 . The $\mathrm{BB}_{\mathrm{j}}$ values in red text indicate a change in the size of the cluster from Table 2. Now the authors take the configurations from Table 3 and identify in Table 5 that there are configurations that now, with $\mathrm{S}_{2}$ equaling 3 seconds do not meet the space constraint (in bold text). It is shown that the configuration selected with a process time $\mathrm{S}_{2}$ equaling 2 seconds, $\left\{\mathrm{B}_{3}, \mathrm{~B}_{4}, \mathrm{~B}_{7}\right\},\left\{\mathrm{B}_{2}, \mathrm{~B}_{5}, \mathrm{~B}_{6}\right\}$, with 586 entities, achieves a total buffer size of 572 entities when the process time of $S_{2}$ is 3 seconds. This scenario in italicized text in Table 5. So the initial buffer cluster set shown in Fig. 8 can remain and still satisfy the space constraints when the process time of $S_{2}$ varies from two to three seconds.

Table 5

Buffer cluster sets and buffer storage savings with $\mathrm{T}_{2}$ at 2 and 3 seconds

\begin{tabular}{|c|c|c|c|c|c|c|c|c|}
\hline Cluster Set & $\begin{array}{c}\text { Size } \\
\text { (No. } \\
\text { Entities) } \\
T_{2}=2 \mathrm{~s}\end{array}$ & $\begin{array}{c}\text { Size } \\
\text { (No. } \\
\text { Entities) } \\
T_{2}=3 \mathrm{~s}\end{array}$ & $\begin{array}{c}\text { Size } \\
\left(\mathrm{m}^{2}\right) \\
\mathrm{T}_{2}=2 \mathrm{~s}\end{array}$ & $\begin{array}{c}\text { Size } \\
\left(\mathrm{m}^{2}\right) \\
\mathrm{T}_{2}=3 \mathrm{~s}\end{array}$ & $\begin{array}{c}\text { Buffer } \\
\text { Storage } \\
\text { Space } \\
\text { Savings } \\
\left(\mathrm{m}^{2}\right) \\
\mathrm{T}_{2}=\mathbf{2 s} \\
\end{array}$ & $\begin{array}{c}\text { Buffer } \\
\text { Storage } \\
\text { Space } \\
\text { Savings } \\
\left(\mathrm{m}^{2}\right) \\
\mathrm{T}_{2}=3 \mathrm{~s}\end{array}$ & $\begin{array}{c}\text { Space } \\
\text { Savings } \\
\% \\
\mathrm{~T}_{2}=2 \mathrm{~s}\end{array}$ & $\begin{array}{c}\text { Space } \\
\text { Savings } \\
\% \\
T_{2}=3 \mathrm{~s}\end{array}$ \\
\hline$\left\{\mathrm{B}_{2}\right\},\left\{\mathrm{B}_{3}\right\},\left\{\mathrm{B}_{4}\right\},\left\{\mathrm{B}_{5}\right\},\left\{\mathrm{B}_{6}\right\},\left\{\mathrm{B}_{7}\right\}^{*}$ & 966 & 928 & 4.83 & 4.64 & & & & \\
\hline$\left\{\mathrm{B}_{2}, \mathrm{~B}_{3}, \mathrm{~B}_{4}, \mathrm{~B}_{5}, \mathrm{~B}_{6}, \mathrm{~B}_{7}\right\}^{* *}$ & 432 & 432 & 2.16 & 2.16 & 2.67 & 2.48 & 55.3 & 53.5 \\
\hline$\left\{\mathbf{B}_{2}, \mathbf{B}_{4}, \mathbf{B}_{5}, \mathbf{B}_{6}, \mathbf{B}_{7}\right\},\left\{\mathbf{B}_{3}\right\}$ & 590 & 509 & 2.95 & 2.55 & 1.88 & 2.10 & 38.9 & 45.2 \\
\hline$\left\{\mathbf{B}_{2}, \mathbf{B}_{5}, \mathbf{B}_{6} \mathbf{B}_{7}\right\},\left\{\mathbf{B}_{3}, \mathbf{B}_{4}\right\}$ & 612 & 555 & 3.06 & 2.78 & 1.77 & 1.87 & 36.7 & 40.2 \\
\hline$\left\{\mathrm{B}_{3} \mathrm{~B}_{5}, \mathrm{~B}_{6}, \mathrm{~B}_{7}\right\},\left\{\mathrm{B}_{2}, \mathrm{~B}_{4}\right\}$ & 615 & 665 & 3.08 & 3.33 & 1.76 & 1.32 & 36.3 & 28.3 \\
\hline$\left\{\mathrm{B}_{3}, \mathrm{~B}_{4}, \mathrm{~B}_{6}, \mathrm{~B}_{7}\right\},\left\{\mathrm{B}_{2}, \mathrm{~B}_{5}\right\}$ & 586 & 572 & 2.93 & 2.86 & 1.90 & 1.78 & 39.3 & 38.4 \\
\hline$\left\{\mathbf{B}_{2}, \mathbf{B}_{4}, \mathbf{B}_{5}, \mathbf{B}_{6}\right\},\left\{\mathbf{B}_{3}, \mathbf{B}_{7}\right\}$ & 573 & 526 & 2.87 & 2.63 & 1.97 & 2.01 & 40.7 & 43.3 \\
\hline$\left\{\mathrm{B}_{2}, \mathrm{~B}_{4}, \mathrm{~B}_{6}, \mathrm{~B}_{7}\right\},\left\{\mathrm{B}_{3}, \mathrm{~B}_{5}\right\}$ & 606 & 630 & 3.03 & 3.15 & 1.80 & 1.49 & 37.3 & 32.1 \\
\hline$\left\{\mathrm{B}_{3}, \mathrm{~B}_{5}, \mathrm{~B}_{7}\right\},\left\{\mathrm{B}_{2}, \mathrm{~B}_{4}, \mathrm{~B}_{6}\right\}$ & 615 & 665 & 3.08 & 3.33 & 1.76 & 1.32 & 36.3 & 28.3 \\
\hline$\left\{\mathrm{B}_{3}, \mathrm{~B}_{5}, \mathrm{~B}_{7}\right\},\left\{\mathrm{B}_{6}\right\},\left\{\mathrm{B}_{2}, \mathrm{~B}_{4}\right\}$ & 615 & 665 & 3.08 & 3.33 & 1.76 & 1.32 & 36.3 & 28.3 \\
\hline$\left\{B_{3}, B_{4}, B_{7}\right\},\left\{B_{2}, B_{5}, B_{6}\right\}$ & 586 & 572 & 2.93 & 2.86 & 1.90 & 1.78 & 39.3 & 38.4 \\
\hline$\left\{\mathrm{B}_{3}, \mathrm{~B}_{4}, \mathrm{~B}_{7}\right\},\left\{\mathrm{B}_{6}\right\},\left\{\mathrm{B}_{2}, \mathrm{~B}_{5}\right\}$ & 586 & 572 & 2.93 & 2.86 & 1.90 & 1.78 & 39.3 & 38.4 \\
\hline$\left\{\mathbf{B}_{3}, \mathbf{B}_{4}, \mathbf{B}_{6}\right\},\left\{\mathbf{B}_{2}, \mathbf{B}_{5}, \mathbf{B}_{7}\right\}$ & 612 & 555 & 3.06 & 2.78 & 1.77 & 1.87 & 36.6 & 40.2 \\
\hline$\left\{\mathbf{B}_{2}, \mathbf{B}_{5}, \mathbf{B}_{7}\right\},\left\{\mathbf{B}_{6}\right\},\left\{\mathbf{B}_{3}, \mathbf{B}_{4}\right\}$ & 612 & 555 & 3.06 & 2.78 & 1.77 & 1.87 & 36.6 & 40.2 \\
\hline$\left\{\mathbf{B}_{2}, \mathbf{B}_{4}, \mathbf{B}_{5}\right\},\left\{\mathbf{B}_{6}\right\},\left\{\mathbf{B}_{3}, \mathbf{B}_{7}\right\}$ & 573 & 526 & 2.87 & 2.63 & 1.97 & 2.01 & 40.7 & 43.3 \\
\hline
\end{tabular}

*Dedicated Buffers

** Optimal Buffer Cluster without space constraints

\section{Conclusion}

This study's results suggest that parametric time-dependent exact methods can be derived and applied with accurate results. This study derived and demonstrated usage of a time based parametric model for $\mathrm{N}$-server, $\mathrm{N}+1$-buffer sequential line to assist production environments in sizing buffers, in particular, buffer clusters appropriately when alternate production line configurations are desired. This study derives an optimization framework that enabled a clustering policy and provides output of the required buffer sizing for that policy. The result reduces the buffers storage space and thus the production line footprint when implemented while ensuring no bottlenecks. The research also reduced the buffer and time search space significantly reducing the number of computations. As demonstrated in the case study, the models can be used to conduct sensitivity analysis of the buffer cluster size by varying parameters such as process time or production demand. 
Related studies are in progress that relax assumptions of the models in this paper and also expand configurations. In particular, studies in process consider unreliable machines. Another area of study is utilizing the model herein to consider when product size varies throughout the manufacturing process. The ability to extract state space models at any given time of interest is a rich area for Operations Research with several applications in industry.

\section{References}

Aghazadeh, S., Hafeznezami, S., Najjar L., and Huq, Z. (2011). The influence of work-cells and facility layout on the manufacturing efficiency. Journal of Facilities Management, 9(3), 213-224.

Becker, C., \& Scholl, A. (2006). A survey on problems and methods in generalized assembly line balancing. European journal of operational research, 168(3), 694-715.

Chan, F. T. S., \& Ng, E. Y. H. (2002). Comparative evaluations of buffer allocation strategies in a serial production line. The International Journal of Advanced Manufacturing Technology, 19(11), 789-800.

Charharsooghi, S.K. and Nahavandi, N. (2003). Buffer allocation problem, a heuristic approach. Scientia Iranica, 10(4), 401-409.

Chow, W. M. (1987). Buffer capacity analysis for sequential production lines with variable process times. International Journal of Production Research,25(8), 1183-1196.

Enginarlar, E., Li, J., \& Meerkov, S. M. (2005). How lean can lean buffers be?. IIE Transactions, 37(4), 333-342.

Enginarlar, E., Li, J., Meerkov, S. M., \& Zhang, R. Q. (2002). Buffer capacity for accommodating machine downtime in serial production lines. International Journal of Production Research, 40(3), 601-624.

Gershwin, S. B. (1987). An efficient decomposition method for the approximate evaluation of tandem queues with finite storage space and blocking. Operations research, 35(2), 291-305.

Gershwin, S. B., \& Schor, J. E. (2000). Efficient algorithms for buffer space allocation. Annals of Operations Research, 93(1-4), 117-144.

Govil, M. K., \& Fu, M. C. (1999). Queueing theory in manufacturing: A survey. Journal of manufacturing systems, 18(3), 214.

Ichikawa, H. (2009, December). Simulating an applied model to optimize cell production and parts supply (Mizusumashi) for laptop assembly. In Winter Simulation Conference (pp. 2272-2280). Winter Simulation Conference.

Kouikoglou, V. S., \& Phillis, Y. A. (1991). An exact discrete-event model and control policies for production lines with buffers. Automatic Control, IEEE Transactions on, 36(5), 515-527.

Kouikoglou, V. S., \& Phillis, Y. A. (1994). Discrete event modeling and optimization of unreliable production lines with random rates. Robotics and Automation, IEEE Transactions on, 10(2), 153-159.

Kouikoglou, V. S., \& Phillis, Y. A. (1995). An efficient discrete-event model for production networks of general geometry. IIE transactions, 27(1), 32-42.

Li, J., E. Blumenfeld, D., Huang, N., \& M. Alden, J. (2009). Throughput analysis of production systems: recent advances and future topics.International Journal of Production Research, 47(14), 3823-3851.

Lim, J. T., Meerkov, S. M., \& Top, F. (1990). Homogeneous, asymptotically reliable serial production lines: theory and a case study. Automatic Control, IEEE Transactions on, 35(5), 524-534.

Liu, C. M. and Lin, C. L. (1994). Performance evaluation of unbalanced serial production lines. International Journal of Production Research, 32(12), 2897-2914.

Logendran, R., \& Karim, Y. (2003). Design of manufacturing cells in the presence of alternative cell locations and material transporters. Journal of the Operational Research Society, 54, 1059-1075.

Matta, A., Runchina, M., \& Tolio, T. (2006). Automated flow lines with shared buffer. In Stochastic Modeling of Manufacturing Systems (pp. 99-120). Springer Berlin Heidelberg.

Morrison, J. R. (2010). Deterministic flow lines with applications. Automation Science and Engineering, IEEE Transactions on, 7(2), 228-239. 
Ramirez-Serrano, A., \& Benhabib, B. (2000). Supervisory control of multiworkcell manufacturing systems with shared resources. Systems, Man, and Cybernetics, Part B: Cybernetics, IEEE Transactions on, 30(5), 668-683.

Senanayake, C. D., \& Subramaniam, V. (2013). Analysis of a two-stage, flexible production system with unreliable machines, finite buffers and non-negligible setups. Flexible Services and Manufacturing Journal, 25(3), 414-442.

So, K. C. (1989). Allocating buffer storages in a flexible manufacturing system. International journal of flexible manufacturing systems, 1(3), 223-237.

Wei, K. C., Tsao, Q. Q., \& Otto, N. C. (1989, December). Estimation of buffer size using stochastic approximation methods. In Decision and Control, 1989., Proceedings of the 28th IEEE Conference on (pp. 1066-1068). IEEE.

Yamashita, H., \& Altiok, T. (1998). Buffer capacity allocation for a desired throughput in production lines. IIE transactions, 30(10), 883-892.

Youssef, A. M., \& ElMaraghy, H. A. (2007). Optimal configuration selection for reconfigurable manufacturing systems. International Journal of Flexible Manufacturing Systems, 19(2), 67-106.

\section{Appendix A. Proof for minimum cluster size}

Lemma 1: Minimum size for cluster $W_{j}$ such that no overflows occur takes place when at least one of the buffers $B_{i}$ in cluster $\mathrm{W}_{\mathrm{j}}$ has reached the maximum number of entities, $\mathrm{MB}_{\mathrm{i}}$.

Take buffers $B_{k}$ and $B_{p}$ that are in cluster $W_{j}$ and output to servers $S_{k}$ and $S_{p}$ respectively where $\mathrm{k}<\mathrm{p}$, and the constraints $\mathrm{MT}_{\mathrm{k}-1}<\mathrm{MT}_{\mathrm{k}}$ and $\mathrm{MT}_{\mathrm{p}-1}<\mathrm{MT}_{\mathrm{p}}$ hold. Recall from Corollary 2 that when $\mathrm{MT}_{\mathrm{k}-1}=\mathrm{MT}_{\mathrm{k}}$ or $\mathrm{MT}_{\mathrm{p}-1}=\mathrm{MT}_{\mathrm{p}}$, the buffer size is 1 . For the proof, the authors observe the buffer inventory profiles of $B_{k}$ and $B_{p}$ at three specific time intervals of the buffer inventory covering the time from the first arrival to buffer $B_{k}$ to the last departure from buffer $B_{p}$ as shown in Fig. 9. In addition, authors also observe when buffers $B_{k}$ and $B_{p}$ are sequential $(\mathrm{p}=\mathrm{k}+1)$ and when they are not $(\mathrm{p}>\mathrm{k}+1)$. Fig. 9 shows the case when $\mathrm{p}=\mathrm{k}+1$. As $\mathrm{p}>\mathrm{k}+1$, the buffer profiles drift apart and the overlap in Time Interval 3 decreases until no overlap exists.

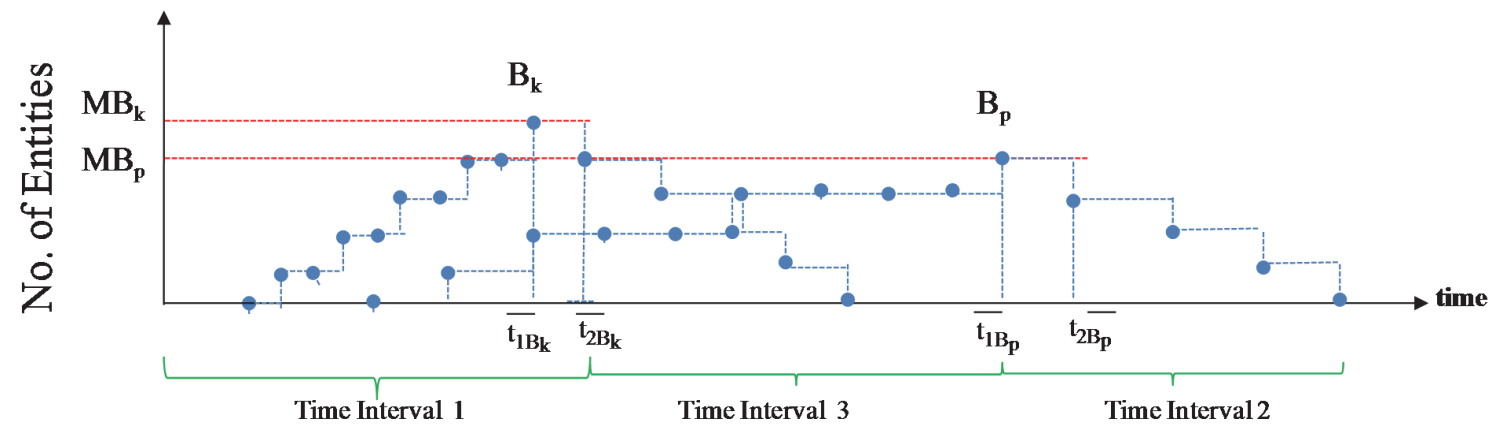

Fig. 9. Buffer profiles of $B_{k}$ and $B_{p}$ and time Intervals 1 through 3 for $p=k+1$

Time Interval 1: $\tau_{\mathrm{k}-1}<\mathrm{t} \leq \overline{\mathrm{t}}_{2 \mathrm{Bk}}\left(B_{k}\right.$ and $B_{p}$ are increasing; $B_{k}$ has reached a maximum)

Buffer $B_{k}$ has its first arrival at $\tau_{\mathrm{k}-1}$ and increases until it reaches $\mathrm{MB}_{\mathrm{k}}$. Buffer $B_{p}$ has its first arrival at $\tau_{\mathrm{p}-1}$ and increases until it reaches its maximum, $\mathrm{MB}_{\mathrm{p}}$. For Buffers $B_{k}$ and $B_{p}$ where $\mathrm{p}=\mathrm{k}+1, \tau_{\mathrm{p}-1}-\tau_{\mathrm{k}-1}=$ $\mathrm{T}_{\mathrm{k}}$. Thus, buffer $B_{p}$ starts increasing $\mathrm{T}_{\mathrm{k}}$ seconds after the first arrival to buffer $B_{k}$. When $\mathrm{p}>\mathrm{k}+1, \tau_{\mathrm{p}-1}-$ $\tau_{\mathrm{k}-1}$ is greater than $\mathrm{T}_{\mathrm{k}}$ meaning that time of the first arrival of $B_{p}$ approaches and can exceed time interval $\left[\bar{t}_{1 B k}, \bar{t}_{2 B k}\right]$ when $B_{k}$ is maximum. When buffer $B_{k}$ is at its maximum $\left(\mathrm{MB}_{\mathrm{k}}\right)$, buffer $B_{p}$ is increasing in size, while after reaching $\mathrm{MB}_{\mathrm{k}}$, buffer $B_{k}$ begins to decline. Therefore, a possible buffer cluster maximum between buffers $B_{k}$ and $B_{p}$ is at $\mathrm{MB}_{\mathrm{k}}$. 
Time Interval 2: $\overline{\mathrm{t}}_{1 \mathrm{Bp}} \leq \mathrm{t} \leq \tau_{\mathrm{p}-1}+(\mathrm{K} 1-1) * \mathrm{MT}_{\mathrm{p}} \quad$ ( $B_{k}$ is decreasing and reaches zero; $B_{p}$ has reached its maximum and begins to decline including its last departure)

The last arrival to buffer $\mathrm{B}_{\mathrm{p}}$ at time $t_{A p K 1}=\tau_{\mathrm{p}-1}+(\mathrm{K} 1-1) * \mathrm{MT}_{\mathrm{p}-1}$

The last departure of buffer $\mathrm{B}_{\mathrm{k}}$ occurs at time $t_{D k K 1}=\tau_{\mathrm{k}-1}+(\mathrm{K} 1-1) * \mathrm{MT}_{\mathrm{k}}$

Subtract these times to get:

$$
\begin{aligned}
& \tau_{\mathrm{p}-1}+(\mathrm{K} 1-1) * \mathrm{MT}_{\mathrm{p}-1}-\tau_{\mathrm{k}-1}-(\mathrm{K} 1-1) * \mathrm{MT}_{\mathrm{k}}= \\
& \tau_{\mathrm{p}-1}-\tau_{\mathrm{k}-1}+(\mathrm{K} 1-1) * \mathrm{MT}_{\mathrm{p}-1}-(\mathrm{K} 1-1) * \mathrm{MT}_{\mathrm{k}}= \\
& \tau_{\mathrm{p}-1}-\tau_{\mathrm{k}-1}-(K 1-1) *\left(\mathrm{MT}_{\mathrm{p}-1}-\mathrm{MT}_{\mathrm{k}}\right)
\end{aligned}
$$

For Buffers $B_{k}$ and $B_{p}$ where $\mathrm{p}=\mathrm{k}+1$ then $\mathrm{MT}_{\mathrm{p}-1}-\mathrm{MT}_{\mathrm{k}}=0$ and $\tau_{\mathrm{p}-1}-\tau_{\mathrm{k}-1}=\mathrm{T}_{\mathrm{k}}$ then (A.1) equals $\mathrm{T}_{\mathrm{k}}$. Therefore, the last departure of $B_{k}$ occurs $\mathrm{T}_{\mathrm{k}}$ seconds prior to the last arrival to buffer $B_{p}$. Thus $B_{k}$ is reaches zero while $B_{p}$ is at a maximum. When $\mathrm{p}>\mathrm{k}+1$, then $\tau_{\mathrm{p}-1}-\tau_{\mathrm{k}-1}$ is greater than $\mathrm{T}_{\mathrm{k}}$ and $\mathrm{MT}_{\mathrm{k}} \leq$ $\mathrm{MT}_{\mathrm{p}-1}$, therefore $(\mathrm{K} 1-1) *\left(\mathrm{MT}_{\mathrm{p}-1}-\mathrm{MT}_{\mathrm{k}}\right) \geq 0$, resulting in (A.1) being greater than $\mathrm{T}_{\mathrm{k}}$. Therefore, a possible buffer cluster maximum between buffers $B_{k}$ and $B_{p}$ occurs at $\mathrm{MB}_{\mathrm{p}}$.

Time Interval 3: $\bar{t}_{2 B k}<\mathrm{t}<\bar{t}_{1 B p}$ ( $B_{k}$ is decreasing; $B_{p}$ is increasing but has not reached a maximum)

At time $\bar{t}_{2 B k}, B_{k}$ has experienced its last arrival (K1) and it has reached a maximum $\mathrm{MB}_{\mathrm{k}}$. Therefore, after this time, only departures occur. Thus in essence, $\mathrm{MB}_{\mathrm{k}}$ indicates the number of departures that are left for buffer $\mathrm{B}_{\mathrm{k}}$ until it reaches zero. During this time interval, buffer $B_{p}$ is increasing (it hasn't reached a maximum yet), meaning it has both arrivals and departures. When $\mathrm{p}=\mathrm{k}+1, \mathrm{MT}_{\mathrm{k}}=\mathrm{MT}_{\mathrm{p}-1}$ indicating that the number of departures remaining at buffer $B_{k}, \mathrm{MB}_{\mathrm{k}}$, is also the number of entities still to arrive at buffer $B_{p}$ and they occur at the same time. However, given that $B_{p}$ is increasing and hasn't reached a maximum, it is also experiencing departures at a rate of $\mathrm{MT}_{\mathrm{p}}$. During this time interval, the quantity of inventory of buffer $B_{k}$ declines from $\mathrm{MB}_{\mathrm{k}}$ to zero. Although Buffer $B_{p}$ entities arrive at the same rate as buffer $B_{k}$ departures, its inventory increases more slowly than the decline of departures from buffer $B_{k}$ given buffer $B_{p}$ also has entities departing at a rate of $\mathrm{MT}_{\mathrm{p}}$ during this time interval. Therefore the sum of the inventory profiles of buffer $B_{k}$ and $B_{p}$ during this time interval will not exceed the maximum inventory observed in time interval (1) or (2) described above. When $\mathrm{p}>\mathrm{k}+1$, buffer $B_{p}$ has its first entity arriving even later than in the $\mathrm{p}=\mathrm{k}+1$ case. Although the decline of buffer $\mathrm{B}_{\mathrm{k}}$ remains the same, buffer $B_{p}$ starting arrival approaches the time when buffer $B_{k}$ approaches $\mathrm{MB}_{\mathrm{k}}$ and the summation of the two inventory profiles will not exceed the maximum inventory observed in time interval (1) or (2) described above. Based on results of the analysis for each of the time intervals, the union of time intervals in (A.2) for each buffer must be searched to find the maximum buffer cluster size BB

$$
\mathrm{t} \in\left[\overline{\mathrm{t}}_{1 \mathrm{~B} 1}, \overline{\mathrm{t}}_{2 \mathrm{~B} 1}\right] \cup\left[\overline{\mathrm{t}}_{1 \mathrm{~B} 2}, \overline{\mathrm{t}}_{2 \mathrm{~B} 2}\right] \cup \ldots\left[\overline{\mathrm{t}}_{1 \mathrm{Bi}}, \overline{\mathrm{t}}_{2 \mathrm{Bi}}\right] \cup \ldots\left[\overline{\mathrm{t}}_{1 \mathrm{~B}_{\mathrm{N}}}, \overline{\mathrm{t}}_{2 \mathrm{~B}_{\mathrm{N}}}\right]
$$

\section{Appendix B. Computational and solution time savings}

Table 6 shows that for this case study, 26 critical time steps were identified to measure the buffer size, resulting in 26 calculations. For Buffer $\mathrm{B}_{6}$, because $\mathrm{MT}_{\mathrm{i}-1}>\mathrm{MT}_{\mathrm{i}}$, no time interval to detect the maximum buffer size is required because buffer size required is always 1 (as discussed in Corollary 2, this is a transport buffer).

Table 7 shows the average savings in time steps processed and average solution time savings benefits based on number of buffers to cluster in the sequential line. The study starts with 6 buffers similar to the example in Section 4 and then doubles the production line size to 12 buffers and 24 buffers respectively. 
$\mathrm{K} 1$ or production demand is also varied (from 100 to 300 ) such that it would cover a production shift interval spread of 8 to 12 hours.

\section{Table 6}

Number of time steps for required buffer size computations

\begin{tabular}{ccccccc}
\hline Element $\mathrm{B}_{\mathrm{i}}$ & $\mathrm{B}_{2}$ & $\mathrm{~B}_{3}$ & $\mathrm{~B}_{4}$ & $\mathrm{~B}_{5}$ & $\mathrm{~B}_{6}$ & $\mathrm{~B}_{7}$ \\
\hline$\overline{\mathrm{t}}_{1 \mathrm{Bi}}$ & 458 & 917 & 1831 & 2292 & 0 & 6434 \\
$\overline{\mathrm{t}}_{2 \mathrm{Bi}}$ & 459 & 918 & 1836 & 2307 & 0 & 6438 \\
$\overline{\mathrm{t}}_{2 \mathrm{Bi}}-\overline{\mathrm{t}}_{1 \mathrm{Bi}}$ & 1 & 1 & 5 & 15 & 0 & 4 \\
Total: $\mathrm{B}_{2}-\mathrm{B}_{7}=26$ & & & &
\end{tabular}

Table 7

Calculation and computation time savings varying $\mathrm{K} 1$

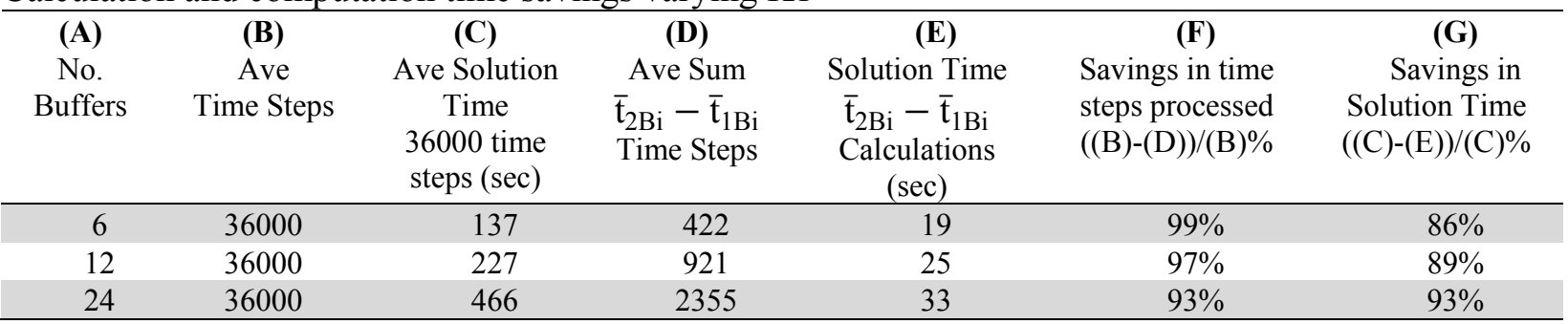

